\title{
Patagonian Eocene Archaeopithecidae Ameghino, 1897 (Notoungulata): systematic revision, phylogeny and biostratigraphy
}

\author{
Bárbara Vera \\ Instituto Argentino de Nivología, Glaciología y Ciencias Ambientales (IANIGLA), CONICET-Mendoza, Ruiz Leal s/n, 5500 Mendoza, \\ Argentina, 〈bvera@mendoza-conicet.gob.ar〉
}

\begin{abstract}
The Archaeopithecidae is a very poorly known group of native ungulates from the Eocene of Patagonia (Argentina), whose alpha taxonomy has remained obscure since Ameghino's times. It is traditionally considered as a family representative of the Casamayoran (middle Eocene) South American Land Mammal Age, and is thought to be morphologically close to the notopithecids. After studying $>200$ specimens from several institutions, including all the type specimens, a taxonomic overestimation is established. Out of the six species considered originally as archaeopithecids, Archaeopithecus rogeri Ameghino, 1897 is here recognized as the only valid name and species; subsequent synonymies are proposed and previous taxonomic hypotheses discarded. This exhaustive revision has permitted improving the knowledge of $A$. rogeri and, for the first time, it has revealed many craniodental characters, which allow amending its diagnosis and differentiating this taxon from other Eocene notoungulates. Archaeopithecus rogeri is a small-sized taxon characterized by its complete and rooted dentition, which is relatively higher than that of other contemporaneous short-crowned notoungulates and shows ontogenetic variation in size and morphology. The body mass range of $A$. rogeri $(1.4-2.5 \mathrm{~kg})$ is comparable to those of notopithecids and some small hegetotheriids. The phylogenetic analysis shows $A$. rogeri is not directly related to any family within Notoungulata, appearing into a polytomy, as a basal taxon of typotherians. The biochronological range of A. rogeri is adjusted to Vacan (middle Eocene) through Barrancan subages (late middle Eocene); older (Riochican, late early Eocene) and younger (Mustersan, late Eocene) records remain to be confirmed.
\end{abstract}

\section{Introduction}

The archaeopithecids are a group of small native ungulates, typically representative of the Casamayoran South American Land Mammal Age (SALMA; Ameghino, 1906; Simpson, 1945, 1967b; Marshall et al., 1983; Cifelli, 1985) and known presently only from Chubut Province, Patagonia (Argentina). However, there are a few older (Riochican SALMA) and younger (Mustersan SALMA) records, yet to be confirmed, that could modify first and last appearances (see below). Little is known about this group-its systematic background is complicated, being frequently related in the literature and collections to notopithecids, which is another Patagonian group of Eocene notoungulates that recently has been revised (Vera, 2013b, 2016). This emphasizes the difficulty in differentiating archaeopithecids from notopithecids based on dental morphology, as well as from other taxa such as Oldfieldthomasiidae or Henricosborniidae, or an "oldfieldthomasiid-archaeopithecidnotopithecine complex" as Simpson (1967b, p. 63) expressed.

The concept of family Archaeopithecidae was created by Ameghino (1897) based on the genus and species Archaeopithecus rogeri, including also the monotypic genus Pachypithecus and its species P. macrognathus Ameghino, 1897. According to Ameghino, Archaeopithecidae shared some features with primates, such as brachydont dentition and a primate-like jaw, which he cited as a reason to consider this family in the Prosimiae, just as did with the family Notopithecidae Ameghino, 1897.

Later, Ameghino (1901) described the species Archaeopithecus alternans and A. rigidus, the genus Ultrapithecus with two species (U. rutilans and U. rusticulus), and the species Guilielmoscottia plicifera, and placed them within Archaeopithecidae. In a subsequent work, Ameghino (1903) described the genus Acropithecus and its type species A. tersus, and placed it in the family Notopithecidae. Concurrently, he transferred to Acropithecus the species Adpithecus plenus Ameghino, 1902, previously described within notopithecids. Thus, the genus Acropithecus sensu Ameghino, 1902, comprised two species: A. tersus and A. plenus. According to one of his last contributions, Ameghino (1906) listed among the 'Notostylopense fauna' (Casamayoran SALMA) both Archaeopithecus and Acropithecus, and placed them in the Archaeopithecidae and Notopithecidae, respectively.

Schlosser (1923) transferred Guilielmoscottia to Notopithecidae, which was accepted by Roth (1927), Simpson (1936, 1945, 1967b), and Scott (1937); however, Ultrapithecus was considered to be a member of the Oldfieldthomasiidae and Pachypithecus a nomen dubium by Simpson (1967b, p. 246). Scott (1937) regarded Archaeopithecus as a member of the Notopithecidae, but provided no justification.

Simpson (1967b, p. 64) argued that Ameghino's original definitions for Notopithecidae and Archaeopithecidae were not 
substantive, and stated that Notopithecus Ameghino, 1897 (type genus of the family Notopithecidae) and Archaeopithecus (type genus of the family Archaeopithecidae) could not be distinguished based on Ameghino's definitions for the two groups. Despite this, Simpson stated that Archaeopithecus was closer to Acropithecus and should be in the same family, but separated from Notopithecus, therefore he transferred Acropithecus to Archaeopithecidae.

According to Simpson (1967b), Archaeopithecus is similar to Acropithecus, and their generic differences rely on the anterior upper premolars. Simpson (1967b) argued that in Archaeopithecus the premolars, and most notably P1-2, are more transverse and symmetrical, the ectoloph columns are less pronounced, and P1 is markedly wider than long. In Acropithecus, $\mathrm{P} 1$ is longer than wide and $\mathrm{P} 2$ is less transverse than in Archaeopithecus, the P1-2 are asymmetrically triangular, and the ectoloph columns are strong (see below).

Simpson (1967b) had hundreds of specimens of Archaeopithecidae available for study as a result of the Scarritt Patagonian Expeditions (1930-1933 and 1933-1934), including the better-preserved specimen. Strikingly, he neither figured any of them nor provided any descriptions, in contrast to what he did for notopithecids (Simpson, 1967b, figs. 22-28). Many of these specimens still lack a catalogue number, and remain labeled only with a field number in some cases, which may explain why Simpson did not include them in his systematic work.

From the most complete specimen, AMNH FM 28782 (partial skull and associated mandible), Simpson (1967b) incorporated substantial systematic changes into the family Archaeopithecidae, with the following nomenclatural actions: (1) he transferred Archaeopithecus rigidus to the genus Acropithecus, establishing the combination Acropithecus rigidus (Ameghino, 1901) and assigning AMNH FM 28782 to A. rigidus; (2) he considered Archaeopithecus alternans and Acropithecus tersus synonymous names of Acropithecus rigidus; and 3) he transferred Notopithecus fossulatus Ameghino, 1897 to the genus Archaeopithecus, establishing (with some doubt) the combination ?A. fossulatus. In summary, after Simpson (1967b), the family Archaeopithecidae comprised the genus Archaeopithecus with two species, A. rogeri (type species) and ?A. fossulatus (Ameghino, 1897), and the genus Acropithecus with a single species, A. rigidus. Under this late name Acropithecus rigidus, Simpson (1967b) placed most of the specimens recovered by the Scarritt Patagonian Expeditions at Cañadón Vaca, Chubut Province (Argentina), which belong to the AMNH collection.

Since Simpson's work (1967b), the members of this group have not been subjected to systematic revision or other detailed studies, and Acropithecus rigidus is practically the only species considered in subsequent studies including Archaeopithecidae (Cifelli, 1985, 1993; Hitz et al., 2006; Reguero and Prevosti, 2010; Reguero et al., 2010; Billet, 2011; Elissamburu, 2012; Vera, 2016), most likely because the specimens of Acropithecus are represented by much more complete material that the type of Archaeopithecus.

From a phylogenetic point of view, the family Archaeopithecidae was regarded as a member of suborder Typotheria (Simpson, 1931, 1967b; Scott, 1937; Mones, 1986; Cifelli, 1993; Billet, 2011), but Simpson (1945) placed it into suborder
Toxodontia as it shared numerous notoungulate characters with Archaeohyracidae and Oldfieldthomasiidae. Later, the analysis by Reguero and Prevosti (2010) places Archaeopithecidae close to Oldfieldthomasiidae, both excluded from Typotheria and, thus, in partial agreement with Simpson's (1945) criterion. Then, in Billet's (2011) analysis, Acropithecus forms part of a large basal bush branching out into the oldfieldthomasiids Oldfieldthomasia, Colbertia and Ultrapithecus; the genus Campanorco; the Interatheriidae; and a clade uniting the Archaeohyracidae, Mesotheriidae and Hegetotheriidae. More recently, a revision of the subfamily Notopithecinae (sensu Simpson, 1945, 1967b) yields novel taxonomic modifications for this group (Vera, 2012a, 2012b, 2013a, 2013b; Vera and Cerdeño, 2014), including the Archaeopithecidae. For the latter, Vera (2013b) hypothesizes an overestimation in the number of species and preliminarily proposes two monospecific genera. Finally, Vera (2016) considers Acropithecus rigidus as the sister taxon of Typotheria sensu Reguero and Prevosti (2010), which includes the notopithecid clade, but she disagrees with the hypothesis of these authors grouping A. rigidus with Oldfieldthomasia; in the minority of topologies (Vera, 2016, fig. 2B), Acropithecus rigidus is nested into the notopithecid clade as the sister taxon of Guilielmoscottia plicifera and Transpithecus obtentus. Based on morphological characters, Vera's (2016) analysis was the first to suggest a possible link between archaeopithecids and notopithecids from a phylogenetic point of view.

In this paper, the type material and many other specimens of archaeopithecids from several institutions are subjected to an exhaustive revision in order to determine the alpha taxonomy and provide robust diagnoses. This work sheds light on the systematic of the group and enables and concrete discussions of biostratigraphic issues, geographic distribution and phylogenetic relationships with respect to other groups. In addition, the large sample of archaeopithecid specimens allows for a body mass estimation and for inferring ecological attributes.

\section{Materials and methods}

Descriptions and comparisons are based on personal observations of 215 catalogued specimens of archaeopithecid from several institutions (see below), including the type material of the Ameghino collection, and the Scarritt Pocket and Egidio Feruglio collections. These specimens come from different localities of Chubut Province, Argentina (Fig. 1) and they are detailed below.

To facilitate the description and comparison, each specimen forming part of a lot is indicated with a letter accompanying the catalog number, particularly for the type specimens from the Ameghino collection. The term Casamayoran SALMA is used in the traditional sense to include the Vacan and Barrancan subages.

The mesiodistal and labiolingual diameters for each tooth were taken at occlusal level with a digital caliper to the nearest $0.1 \mathrm{~mm}$. Each specimen was assigned to one of three wear stages (based on upper and lower cheek molars features): little wear, moderate wear and heavy wear (see Description). It should be noted that this procedure became subjective and difficult when assigning a particular wear stage to an isolated teeth, which 


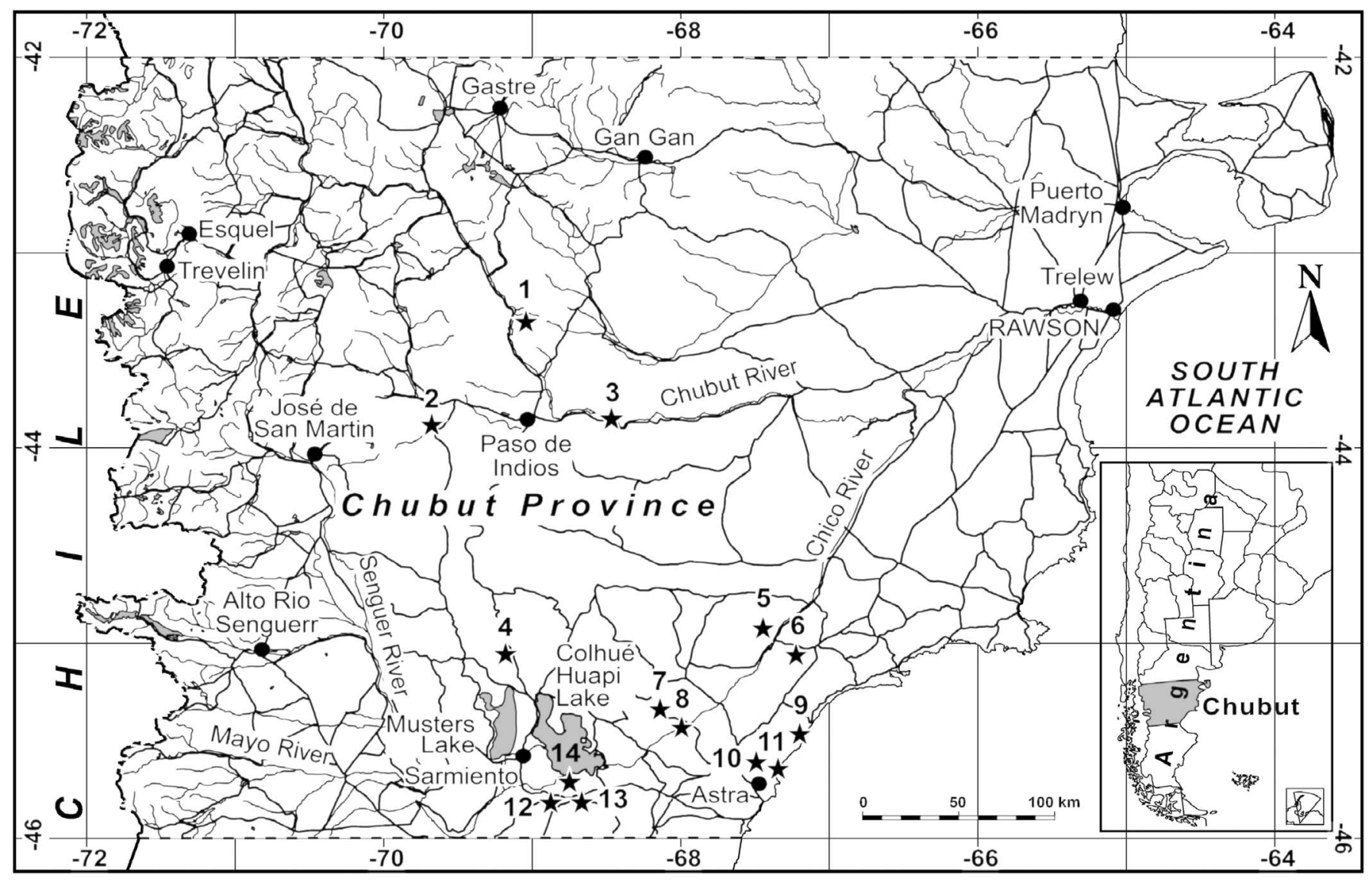

Figure 1. Localities mentioned in the text, from which most of the studied specimens of Archaeopithecus rogeri derive. (1) Cerro Solo, (2) Lomas Blancas, (3) Las Cascadas, (4) Campo Muriette, (5) El Pajarito, (6) Oeste Río Chico, (7) Cabeza Blanca, (8) Cañadón Vaca, (9) Cañadón Hondo, (10) Bajo Palangana, (11) Pico Salamanca, (12) Bahía Solano, (13) Cañadón Blanco, (14) Colhué Huapi (and vicinity).

occurs with some specimens considered in the present study (see below). In addition, upper teeth are much more numerous than lower dentition, particularly P4, M1 and M2. Descriptive statistics (mean, maximum, minimum, standard deviation, coefficient variation) were used to describe all upper and lower cheek teeth (Tables 1-2) and for each wear category separately (Supplemental Data 3). Eight specimens with complete P4-M1 tooth rows representing the three wear stages were chosen to evaluate metric changes throughout ontogeny. Graphical and statistical procedures were performed using Microsoft Excel 2010 and InfoStat (Di Rienzo et al., 2016).

A phylogenetic analysis was performed based on a modified version of Vera's (2016) matrix. It consists of 29 terminal taxa and 87 morphological characters (0-57, upper and lower dentition; 58-70, skull and mandible; and 71-86, postcranium). The polarization of the characters was based on out-group comparison criteria using the notoungulate Simpsonotus praecursor Pascual, Vucetich, and Fernández (1978). With respect to Vera (2016), some characters previously unknown for archeopithecids are coded differently in the present study (see below) and Archaeohyrax patagonicus was included as representative of Archaeohyracidae. When no information was known for a taxon, characters were scored as missing data; when a character was not present, it was scored as non-applicable. All characters are treated as unordered. They are referred to in brackets with the character state in superscript. Maximum parsimony under equal weights was assumed. The computer program TNT 1.1 (Goloboff et al., 2008) was used to conduct heuristic searches with the Tree Bisection Reconnection swapping algorithm (TBR), using 1000 random addition sequences and saving 100 trees. Subsequent searches were repeated from previously obtained trees (trees from RAM), in order to save all the most parsimonious topologies. Branch support was estimated by absolute and relative Bremer support-BS- (Bremer, 1990) and Symmetric Resampling (Goloboff et al., 2003). The characters and states, and the data matrix used in this analysis are explained in Supplemental Data 1 and Supplemental Data 2, respectively.

Body masses were estimated for archaeopithecids and notopithecids using Vera's (2013b) dataset and applying the equations from Janis (1990) and Scarano et al.'s (2011) based on dental measurements. Three variables were selected from Janis (1990), lengths of first lower molar (FLML), second upper molar (SUML) and lower molar row (LMRL). In turn, four variables were applied on the Scarano et al.'s (2011) models, lengths of first, second, and third lower molars (FLML, SLML, TLML), and length of second upper molar (SUML). In particular for Notopithecus, body mass was also inferred from astragalar parameters selected from Tsubamoto (2014), which are based on the transverse width of the tibial trochlea (Li1), proximodistal length of the lateral trochlear ridge of the tibial trochlea (Li2), proximodistal length of the astragalus (Li5), and dorsoventral thickness of the medial part of the astragalus (Li9). 
Table 1. Dimensions (mm) of upper dentition of Archaeopithecus rogeri. MD = mesiodistal diameter; LL = labiolingual diameter; SW = stage of wear: 1 , little; 2, middle; 3 , heavy (see text for details); CV (coefficient of variation) $=100 \times(\mathrm{SD} / \mathrm{mean})$. Approximate values in parentheses. Dashes represent not measured dimensions (broken tooth or alveolus).

\begin{tabular}{|c|c|c|c|c|c|c|c|c|c|c|c|c|c|c|c|}
\hline \multirow[b]{2}{*}{ Specimen } & \multirow[b]{2}{*}{ SW } & $\mathrm{P}$ & & & 2 & $\mathrm{P}$ & 3 & $\mathrm{P}$ & & $\mathrm{M}$ & 11 & M & 12 & M & 13 \\
\hline & & MD & LL & MD & LL & MD & LL & MD & LL & MD & LL & MD & LL & MD & LL \\
\hline AMNH FM 15902c & 2 & & & & & & & & & 4.0 & - & & & & \\
\hline AMNH FM 28534 & 2 & & & & & & & & & 4.2 & 6.5 & 4.5 & - & & \\
\hline AMNH FM 28782 & 3 & - & - & 4.6 & 5.5 & 4.5 & 6.8 & 4.7 & 7.0 & 4.3 & 7.5 & 4.9 & 7.9 & & \\
\hline AMNH FM 28824 & 1 & & & & & & & & & & & $(5.7)$ & & & \\
\hline AMNH FM 28827 & 3 & & & & & & & 4.2 & 6.4 & 4.1 & 6.9 & 5.1 & 7.0 & & \\
\hline AMNH FM 28841 & 2 & & & 4.0 & 6.0 & 4.0 & 6.3 & & & & & & & & \\
\hline AMNH FM 28868 & 2 & & & 3.6 & - & 3.7 & 5.8 & 4.0 & 6.1 & - & - & & & & \\
\hline AMNH FM 28871 & 2 & & & & & & & & & 4.3 & 6.3 & & & 4.6 & 4.8 \\
\hline AMNH FM 28884c & 3 & & & 3.9 & 4.5 & 4.1 & 5.8 & & & & & & & & \\
\hline AMNH FM 28884b & 3 & & & & & & & & & & & & & 4.9 & 6.1 \\
\hline AMNH FM 28886 & 2 & & & & & & & 4.7 & 5.9 & & & & & & \\
\hline AMNH FM 28895 & 3 & & & & & 4.0 & - & $(4.1)$ & - & & & & & & \\
\hline AMNH FM 144692 & 3 & & & & & & & & & 4.8 & - & 5.1 & - & 4.9 & 6.3 \\
\hline AMNH FM 144695 & 3 & & & & & & & 3.9 & 6.3 & 3.4 & 6.4 & & & & \\
\hline AMNH FM 144696 & 2 & & & & & & & & & & & & & 4.3 & 5.7 \\
\hline MACN-A 10813a & 2 & & & & & 3.9 & 6.7 & $(4.6)$ & - & 4.4 & 6.3 & - & - & & \\
\hline MACN-A 10813b & 1 & & & & & & & 4.3 & 6.1 & 4.2 & 6.3 & 4.8 & - & & \\
\hline MACN-A $10813 c$ & 1 & & & & & & & 3.6 & 5.2 & 4.6 & 4.9 & 4.8 & 6.0 & & \\
\hline MACN-A $10813 d$ & 2 & & & & & & & & & 3.9 & - & 4.8 & - & 4.5 & 6.4 \\
\hline MACN-A $10813 \mathrm{e}$ & 1 & 3.6 & 4.2 & 4.2 & 5.0 & 4.0 & 5.5 & & & & & & & & \\
\hline MACN-A $10813 f$ & 1 & & & & & & & 4.4 & 6.6 & & & & & & \\
\hline MACN-A 10813g & 2 & & & & & & & & & - & 5.6 & 5.0 & 6.4 & & \\
\hline MACN-A $10813 \mathrm{~h}$ & 2 & & & & & & & & & 4.5 & 6.3 & & & & \\
\hline MACN-A 10813i & 1 & & & & & & & 4.6 & 6.2 & & & & & & \\
\hline MACN-A 10815 & 2 & & & & & & & & & - & 6.3 & 5.6 & 6.9 & 4.9 & 6.1 \\
\hline MACN-A 10816 & 2 & 3.6 & 4.1 & 3.8 & 5.6 & 4.3 & 6.0 & 4.9 & 6.4 & 3.8 & 6.5 & 4.4 & 7.0 & & \\
\hline MACN-A 10831 & 1 & & & & & & & & & & & & & 5.1 & 6.0 \\
\hline MACN-A $10833 c$ & & & & & & & & & & & & 4.7 & 7.0 & & \\
\hline MACN-A 10850a & 3 & & & & & & & & & & & & & 4.8 & 6.0 \\
\hline MACN-A 10850b & 3 & & & & & & & & & & & & & 4.6 & 6.4 \\
\hline MACN-A $10850 \mathrm{c}$ & 1 & & & & & & & & & & & & & 4.3 & 6.1 \\
\hline MACN-A 10851a & 3 & & & & & & & & & $(3.4)$ & - & 4.8 & 7.5 & $(3.4)$ & - \\
\hline MACN-Pv 11237 & 2 & & & & & & & & & 3.7 & - & 4.6 & 7.0 & & \\
\hline MACN-Pv 12842 & 2 & & & & & & & & & $(4.4)$ & - & $(4.9)$ & - & $(4.9)$ & - \\
\hline MGP 31362 & 3 & & & & & & & & & 3.9 & 6.3 & $(4.6)$ & 6.6 & - & 6.0 \\
\hline MGP 31595 & 1 & & & & & & & & & 4.2 & 5.7 & & & & \\
\hline MGP 31600 & 1 & & & & & 4.0 & 6.1 & & & & & & & & \\
\hline MGP 31606 & 3 & & & & & 4.0 & 6.0 & & & & & & & & \\
\hline MGP 31658 & 2 & & & & & & & & & & & & & 4.1 & 5.9 \\
\hline MGP 31729 & 1 & & & & & & & & & 3.7 & 5.8 & & & & \\
\hline MGP 31753 & 2 & & & & & 3.7 & 5.4 & & & & & & & & \\
\hline MGP 31769 & 2 & & & & & 3.7 & 5.1 & & & & & & & & \\
\hline MGP 31777 & 2 & & & & & 3.7 & 5.3 & & & & & & & & \\
\hline MLP 34-V-22-7 & 2 & & & & & & & & & 4.3 & 6.0 & & & & \\
\hline MLP 61-VIII-3-148 & 3 & & & 3.5 & $(4.0)$ & 3.8 & 5.2 & 4.1 & $(6.0)$ & 4.5 & 6.2 & $(4.3)$ & $(6.0)$ & & \\
\hline MLP 61-VIII-3-176 & 1 & & & & & & & 3.8 & 5.6 & 4.6 & 5.8 & 4.8 & 6.6 & & \\
\hline MLP 61-VIII-3-177 & 2 & & & & & & & 4.2 & 6.0 & $(4.4)$ & 6.3 & $(4.5)$ & $(7.0)$ & & \\
\hline MLP 61-VIII-3-427 & 1 & & & & & & & & & & & & & 4.5 & 5.0 \\
\hline MLP 61-VIII-3-430 & 2 & & & & & & & 4.9 & 6.2 & & & & & & \\
\hline MLP 66-V-9-16 & 1 & & & & & & & 5.0 & 6.8 & & & 4.9 & 7.2 & & \\
\hline MLP 66-V-10-4 & 2 & & & & & & & 4.9 & 6.9 & & & & & & \\
\hline MLP 75-II-3-19 & 1 & & & & & & & 4.9 & 6.9 & & & & & & \\
\hline MLP 79-I-17-10 & 2 & & & & & & & 3.8 & 5.0 & 4.4 & 6.0 & - & - & & \\
\hline MLP 79-I-17-20 & 1 & & & & & & & 4.1 & 5.7 & - & - & 5.3 & 6.6 & & \\
\hline MLP 79-I-17-36 & 2 & & & & & 4.0 & 5.6 & & & & & & & & \\
\hline MLP 79-I-17-37 & 2 & & & & & & & 4.3 & 5.9 & & & & & & \\
\hline MLP 79-I-17-41 & 1 & & & & & & & & & & & 4.9 & 5.4 & & \\
\hline MLP 79-I-17-48 & 2 & & & & & & & 3.7 & 5.6 & & & & & & \\
\hline MLP 79-I-17-50 & 2 & & & & & & & 4.1 & 5.4 & 4.7 & 6.0 & - & 6.8 & & \\
\hline MLP 93-XI-22-3f & 3 & & & & & & & 4.7 & 6.5 & & & & & & \\
\hline MLP 93-XI-22-3g & 2 & & & & & & & & & 5.2 & 6.9 & & & & \\
\hline MMdP-M 727 & 2 & 3.0 & 2.3 & 4.2 & 5.3 & 4.1 & 6.4 & 4.5 & $(6.8)$ & 4.2 & 6.6 & 4.9 & $(7.6)$ & $(4.4)$ & $(6.8)$ \\
\hline MNHN-CAS 739 & 2 & & & & & 4.1 & 5.8 & 4.0 & 6.6 & - & - & 4.6 & 7.2 & & \\
\hline MNHN-CAS 751 & 2 & & & & & & & 4.1 & 6.4 & & & & & & \\
\hline MPEF-PV 1570a & 3 & & & & & & & 4.4 & 6.4 & & & & & & \\
\hline MPEF-PV 1570b & 2 & & & & & & & & & 4.8 & 5.9 & & & & \\
\hline MPEF-PV 1570c & 2 & & & & & & & & & & & 5.2 & 6.2 & & \\
\hline MPEF-PV 1570d & 1 & & & & & & & & & & & & & 4.2 & 5.7 \\
\hline MPEF-PV 1580b & 2 & & & & & & & & & & & $(4.6)$ & - & $(4.1)$ & - \\
\hline MPEF-PV 1580c & 3 & & & & & & & 3.3 & 5.6 & & & & & & \\
\hline PVL 210 & 1 & & & & & & & & & & & 5.0 & 7.8 & & \\
\hline PVL 242 & 2 & & & & & 4.3 & 5.8 & & & & & & & & \\
\hline Number & & 3 & 3 & 8 & 7 & 18 & 17 & 30 & 28 & 29 & 25 & 26 & 20 & 16 & 15 \\
\hline Range & & $3.0-3.6$ & $2.3-4.1$ & $3.5-4.6$ & $4.0-6.0$ & $3.7-4.5$ & $5.1-6.8$ & $3.3-5.0$ & $5.0-7.0$ & $3.4-5.2$ & $4.9-7.5$ & $4.3-5.7$ & $6.0-7.9$ & $4.1-5.1$ & $4.8-6.8$ \\
\hline Mean & & 3.4 & 3.5 & 4.0 & 5.1 & 4.0 & 5.9 & 4.3 & 6.2 & 4.2 & 6.2 & 4.9 & 6.9 & 4.6 & 5.9 \\
\hline SD & & 0.3 & 1.0 & 0.4 & 0.7 & 0.2 & 0.5 & 0.4 & 0.5 & 0.4 & 0.5 & 0.3 & 0.5 & 0.3 & 0.5 \\
\hline
\end{tabular}


Table 2. Dimensions (mm) of lower dentition of Archaeopithecus rogeri. $\mathrm{MD}=$ mesiodistal diameter; $\mathrm{LL}=$ labiolingual diameter; SW = stage of wear: 1 , little; 2 , middle; 3 , heavy; CV (coefficient of variation) $=100 \times(\mathrm{SD} /$ mean). Approximate values in parentheses. Dashes represent not measured dimensions (broken tooth or alveolus).

\begin{tabular}{|c|c|c|c|c|c|c|c|c|c|c|c|c|c|}
\hline \multirow[b]{2}{*}{ Specimen } & \multirow[b]{2}{*}{ SW } & \multicolumn{2}{|c|}{$\mathrm{p} 2$} & \multicolumn{2}{|c|}{ p3 } & \multicolumn{2}{|c|}{$\mathrm{p} 4$} & \multicolumn{2}{|c|}{$\mathrm{m} 1$} & \multicolumn{2}{|c|}{$\mathrm{m} 2$} & \multicolumn{2}{|c|}{$\mathrm{m} 3$} \\
\hline & & MD & LL & MD & LL & MD & LL & MD & LL & MD & LL & MD & LL \\
\hline AMNH FM 28705 & 3 & 3.9 & 2.3 & 4.0 & 2.9 & 4.0 & 3.3 & 4.1 & 3.2 & & & & \\
\hline AMNH FM 28782 & 3 & 4.4 & 2.7 & 4.7 & 3.1 & 5.0 & 3.6 & 4.5 & 3.9 & 4.8 & 3.9 & 5.9 & 3.4 \\
\hline AMNH FM 28801 & 2 & & & 4.3 & 3.0 & 4.5 & 3.3 & 4.2 & 3.5 & & & & \\
\hline AMNH FM 28803 & 1 & & & & & 4.7 & 3.5 & 4.6 & 3.5 & 5.0 & 3.8 & & \\
\hline AMNH FM 28804 & 1 & & & $(4.8)$ & 3.1 & 5.3 & 3.5 & & & & & & \\
\hline AMNH FM 28805 & 1 & & & & & & & $(4.2)$ & $(2.8)$ & 5.0 & 3.3 & & \\
\hline AMNH FM 28840 & 3 & & & & & 4.4 & 3.3 & 4.5 & 3.3 & 4.6 & 3.8 & & \\
\hline AMNH FM 28842 & 2 & & & 4.3 & 3.0 & 4.4 & 3.2 & & & & & & \\
\hline AMNH FM 28872 & 1 & & & & & & & & & & & 4.8 & 2.9 \\
\hline AMNH FM 28884d & 3 & & & & & & & 4.2 & $(3.1)$ & 4.4 & (3.3) & $(6.3)$ & $(3.0)$ \\
\hline AMNH FM144688 & 1 & & & & & 4.6 & 3.4 & 4.2 & 3.2 & & & & \\
\hline AMNH FM144689 & 1 & & & & & & & & & 4.8 & 3.7 & 6.2 & 3.1 \\
\hline AMNH FM 144690 & 2 & & & & & & & 5.0 & 3.5 & & & & \\
\hline AMNH FM 144691 & 1 & & & 4.6 & 3.1 & & & & & & & & \\
\hline AMNH FM 144693 & 2 & & & & & 4.4 & 3.0 & 4.4 & 3.4 & & & & \\
\hline AMNH FM 144694 & 3 & & & & & & & & & & & 5.6 & 3.2 \\
\hline MACN-A 10824a & 1 & & & & & 4.2 & 3.0 & $(4.7)$ & 3.1 & & & & \\
\hline MACN-A $10841 \mathrm{c}$ & 2 & & & & & & & 4.0 & 3.1 & 5.6 & 3.3 & & \\
\hline MGP 29028 & 2 & & & & & & & & & 4.5 & 3.5 & 5.7 & 3.3 \\
\hline MGP 29056 & 2 & & & & & & & 3.7 & 2.9 & - & - & 5.4 & 2.9 \\
\hline MGP 31596 & 2 & & & & & & & & & 4.5 & 3.3 & & \\
\hline MGP 31597 & 2 & & & & & & & 3.4 & 3.1 & & & & \\
\hline MGP 31598 & 1 & & & & & & & & & 4.5 & 3.3 & & \\
\hline MGP 31599 & 2 & & & & & & & & & & & 5.4 & 3.1 \\
\hline MGP 31601 & 1 & & & & & & & & & 4.6 & - & & \\
\hline MGP 31657 & 2 & & & & & & & & & 4.4 & 3.5 & & \\
\hline MGP 31658 & 2 & & & & & & & & & 3.6 & 2.8 & 4.9 & 2.7 \\
\hline MGP 31720 & 2 & & & & & & & & & 4.6 & 3.3 & & \\
\hline MGP 31727 & 1 & & & & & & & & & & & 5.8 & 3.4 \\
\hline MGP 31759 & 1 & & & & & & & & & 4.6 & 3.1 & & \\
\hline MGP 31767 & 3 & & & & & & & 4.2 & 3.2 & & & & \\
\hline MLP 12-1529 & 1 & & & & & & & & & 4.9 & 4.1 & & \\
\hline MLP 66-V-10-19 & 1 & & & & & & & & & & & 6.5 & 3.7 \\
\hline MLP 75-II-3-20 & 1 & & & & & & & & & 5.0 & 3.8 & & \\
\hline MLP 93-XI-22-3a & 2 & & & & & & & 4.7 & 3.6 & 5.0 & 3.8 & & \\
\hline MLP 93-XI-22-3b & 2 & & & & & & & & & & & 5.4 & 3.2 \\
\hline MLP 93-XI-22-3c & 1 & & & & & & & & & & & 5.3 & 3.1 \\
\hline MLP 93-XI-22-3d & 1 & & & & & & & & & & & 5.5 & 3.5 \\
\hline MLP 93-XI-22-3e & 1 & & & & & & & & & & & 6.6 & 3.4 \\
\hline MLP 93-XI-22-3h & 1 & & & & & & & & & & & 5.4 & 3.2 \\
\hline MNHN-CAS 741 & 3 & & & & & & & 4.1 & 3.2 & & & & \\
\hline PVL 162 & 2 & & & & & 4.6 & 3.4 & (4.9) & - & & & & \\
\hline PVL 163 & 2 & & & & & & & 4.6 & 3.5 & 4.9 & 3.1 & 6.6 & 3.4 \\
\hline PVL 165 & 3 & & & & & 4.2 & 2.8 & 4.6 & 3.3 & & & & \\
\hline PVL 166 & 1 & & & & & & & 4.4 & 3.4 & 4.5 & 3.6 & & \\
\hline PVL 167 & 2 & & & & & 5.1 & 2.9 & & & & & & \\
\hline PVL 199 & 1 & & & & & 5.2 & 3.3 & & & & & & \\
\hline PVL 232 & 3 & & & & & & & (4.8) & - & & & & \\
\hline Number & & 2 & 2 & 6 & 6 & 14 & 14 & 22 & 19 & 20 & 19 & 17 & 17 \\
\hline Range & & $3.9-4.4$ & $2.3-2.7$ & $4.0-4.8$ & $2.9-3.1$ & $4.0-5.3$ & $2.8-3.6$ & $3.4-5.0$ & $2.9-3.9$ & $3.6-5.6$ & $2.8-4.1$ & $4.8-6.6$ & $2.7-3.7$ \\
\hline Mean & & 4.1 & 2.5 & 4.5 & 3.0 & 4.6 & 3.2 & 4.4 & 3.3 & 4.7 & 3.5 & 5.7 & 3.2 \\
\hline SD & & 0.3 & 0.3 & 0.3 & 0.1 & 0.4 & 0.2 & 0.4 & 0.2 & 0.4 & 0.3 & 0.6 & 0.2 \\
\hline
\end{tabular}

Mean values for each model and taxon, as well as the average total, are listed in Table 3. Additionally, the obtained values are compared with those previously inferred for archaeopithecids and notopithecines (Elissamburu, 2012; Vera, 2013b) and for other similar-sized notoungulates (Scarano et al., 2011; Cassini et al., 2012a, 2012b; Elissamburu, 2012).

Repositories and institutional abbreviations.-American Museum of Natural History, Fossil Mammals (AMNH FM), New York, USA; Museo Argentino de Ciencias Naturales "Bernardino Rivadavia," Ameghino and Paleovertebrata collections (MACN-A/Pv), Buenos Aires, Argentina; Museo di Geologia e Paleontologia (MGP), Università degli Studi di Padova, Italy; Museo de La Plata (MLP), La Plata, Argentina; Museo de Ciencias Naturales de Mar del Plata "Lorenzo
Scaglia" (MMdP), Mar del Plata, Argentina; Muséum national d'Histoire naturelle, Casamayoran collection (MNHN-CAS), Paris, France; Museo Paleontológico "Egidio Feruglio", Vertebrate Paleontology collection (MPEF-PV), Trelew, Argentina; Colección Paleontología de Vertebrados Lillo, Instituto Miguel Lillo (PVL), Tucumán, Argentina; Yale Peabody Museum, Vertebrate Paleontology Princeton University Collection (YPM-PU), New Haven, Connecticut, USA.

\section{Systematic background}

In this section, all erected extinct species into the family Archaeopithecidae are comprehensively reviewed. The type species of the family, Archaeopithecus rogeri, is based on the specimen MACN-A 10816 (Fig. 2.1), catalogued as holotype 
Table 3. Body masses (mean values in kg) for Archaeopithecus rogeri and notopithecids based on different authors (dataset taken from Vera, 2013b). FLML, first lower molar length; SUML, second upper molar length; LMRL, lower molar row length; SLML, second lower molar length; TLML, third lower molar length; Li1, transverse width of the tibial trochlea; Li2, proximodistal length of the lateral trochlear ridge of the tibial trochlea; Li5, proximodistal length of the astragalus; Li9, dorsoventral thickness of the medial part of the astragalus; Ar1 = Li1 x Li2; Ar3 = Li1 x Li9.

\begin{tabular}{|c|c|c|c|c|c|c|c|c|c|c|c|c|}
\hline \multirow[b]{2}{*}{ Taxon/allometric equation } & \multicolumn{3}{|c|}{ Janis (1990) } & \multicolumn{4}{|c|}{ Scarano et al. (2011) } & \multicolumn{4}{|c|}{ Tsubamoto (2014) } & \multirow[b]{2}{*}{ Average total } \\
\hline & FLML & SUML & LMRL & FLML & SLML & TLML & SUML & Li1 & Li5 & Ar1 & Ar3 & \\
\hline$\overline{\text { Archaeopithecus rogeri }}$ & 1.47 & 1.25 & 1.36 & 1.75 & 1.43 & 2.57 & 1.51 & & & & & 1.62 \\
\hline $\mathrm{n}$ & 21 & 18 & 2 & 21 & 12 & 10 & 18 & & & & & \\
\hline sd & 0.40 & 0.32 & 0.41 & 0.38 & 0.29 & 0.45 & 0.31 & & & & & \\
\hline Notopithecus adapinus & 1.06 & 0.87 & 0.67 & 1.35 & 1.03 & 1.99 & 1.13 & 1.80 & 1.85 & 1.82 & 1.82 & 1.40 \\
\hline $\mathrm{n}$ & 79 & 63 & 22 & 79 & 77 & 64 & 63 & 1 & 1 & 1 & 1 & \\
\hline sd & 0.38 & 0.21 & 0.18 & 0.37 & 0.25 & 0.35 & 0.22 & & & & & \\
\hline Antepithecus brachystephanus & 1.71 & 1.53 & 0.99 & 1.97 & 1.39 & 2.40 & 1.79 & & & & & 1.68 \\
\hline $\mathrm{n}$ & 47 & 12 & 8 & 47 & 44 & 33 & 12 & & & & & \\
\hline sd & 0.51 & 0.35 & 0.14 & 0.44 & 0.21 & 0.35 & 0.34 & & & & & \\
\hline Transpithecus obtentus & 1.75 & 1.35 & 1.30 & 2.01 & 1.52 & 3.17 & 1.61 & & & & & 1.82 \\
\hline $\mathrm{n}$ & 8 & 9 & 3 & 8 & 12 & 13 & 9 & & & & & \\
\hline sd & 0.48 & 0.27 & 0.18 & 0.42 & 0.26 & 0.28 & 0.26 & & & & & \\
\hline Guilielmoscottia plicifera & 2.63 & 1.92 & 1.83 & 2.76 & 2.14 & 3.20 & 2.15 & & & & & 2.38 \\
\hline $\mathrm{n}$ & 11 & 3 & 8 & 11 & 12 & 11 & 3 & & & & & \\
\hline sd & 0.67 & 0.34 & 0.27 & 0.55 & 0.40 & 0.80 & 0.31 & & & & & \\
\hline
\end{tabular}

and consisting of a maxillary fragment with six teeth, here recognized as right $\mathrm{P} 1-\mathrm{M} 2$, coming from the Casamayoran levels of Sarmiento Formation (Patagonia, Argentina), but without specific locality information. Originally, Ameghino described upper premolars and molars for this species, giving the P1-M3 length $(27 \mathrm{~mm})$, and he also described a mandible fragment, providing several dimensions. Unfortunately, this mandible is presently lost and only the maxilla was originally figured (Ameghino, 1897, fig. 8; 1904, fig. 402). Although he described the complete upper molar series, the M3 is missing in the maxilla. It is worth noting that M3 is dotted in Ameghino's figure, which means that this molar was always absent.

Although MACN-A 10816 is poorly preserved, it is possible to distinguish the following features: triangular upper premolars; low and well-developed mesial cingulum on P2-4 and upper molars; very undulating ectoloph in P2-4; upper molars wider than longer (LLD > MDD); and deep lingual sulcus in M1-2, very shallow in P4, and absent in P2-3. This combination of features is observed in AMNH FM 28782 (Acropithecus rigidus sensu Simpson, 1967b), MACN-A 10813 (lot catalogued as Archaeopithecus rigidus, see below), and MACN-A 10851a (type of Acropithecus plenus), although the presence of a lingual sulcus in $\mathrm{P} 4$ cannot be corroborated in the last specimen. In addition, the measurements of all these specimens are comparable (Table 1).

The holotype of the species Archaeopithecus alternans is the specimen MACN-A 10815 (maxillary fragment with left M1-3; Fig. 2.2), which comes from 'Oeste de Río Chico' (Ameghino's locality from Chubut Province, Fig. 1; Simpson, 1967a). Ameghino (1901, p. 359) described Archaeopithecus alternans as a larger species than A. rogeri and provided the length of M1-3 (14 mm). M1 of MACN-A 10815 is squarer than that of MACN-A 10816 (A. rogeri), which is more rectangular certainly due to its greater degree of wear, although the length in both is practically the same (Table 1). Indeed, dimensions of M2 and M3 in MACN-A 10815 match the M3s of MACN-A 10850 (type specimen of Acropithecus tersus, see below) and of other specimens, such as MLP 79-I-17-20 (Table 1). In addition, MACN-A 10815 (Fig. 2.2) is morphologically very similar (fossettes configuration, undulated ectoloph, lingual sulcus on molars, mesial and distal cingula) to MACN-A 10813 (Fig. 2.3, 2.6, 2.10).

Archaeopithecus rigidus was defined by Ameghino (1901, p. 359) basically by its larger size compared with A. rogeri and by having squared upper molars with faintly undulating labial face and lingual sulcus. Ameghino also provided the length of P2-M3 (30 mm). The material catalogued as type of $A$. rigidus has the number MACN-A 10813 (Fig. 2.3-2.11) and it is a lot with seven maxillary fragments and two isolated teeth, coming from 'Oeste de Río Chico' (Fig. 1). The lot consists of: MACNA 10813a, maxillary fragment with left P2-M2 (Fig. 2.3); MACN-A 10813b, maxillary fragment with left P4-M2 (Fig. 2.4); MACN-A 10813c, maxillary fragment with right P4-M2 (Fig. 2.5; P4, presently broken, probably corresponds to that figured by Ameghino, 1904, fig. 404); MACN-A 10813d, maxillary fragment with right M1-3 (Fig. 2.6); MACN-A 10813e, maxillary fragment with right P1-3 (Fig. 2.7); MACN-A 10813f, maxillary fragment with right P4 (Fig. 2.8; similar to the P4 pictured by Ameghino, 1904, fig. 403); MACN-A 10813g, maxillary fragment with right M1-2 (Fig. 2.9); MACN-A 10813h, right M1 or M2 (Fig. 2.10); and MACN-A 10813i, left P4 (Fig. 2.11; this matches the P4 figured by Ameghino, 1904, fig. 405).

Simpson (1967b, p. 65) identified the same number of specimens in lot MACN-A 10813; he selected the maxilla, here named MACN-A 10813b, as the lectotype of Archaeopithecus rigidus and mentioned that the other specimens in the lot could all be syntypes. Bearing in mind that Ameghino (1901) provided only the length of a P2-M3 series, and there is not such a series represented among the specimens in lot MACN-A 10813, two explanations are possible: the maxilla on which Ameghino based his description (and measurements) is lost or, more likely, Ameghino used several elements in combination, as he did for Archaeopithecus rogeri (see above). Whatever was the case, the decision of the first reviewer (Simpson, 1967b) is here accepted and MACN-A 10813b (Fig. 2.4) is considered the lectotype of Archaeopithecus rigidus.

Specimen MACN-A 10813b (Fig. 2.4) is characterized by a narrow mesial cingulum and a high distal cingulum on molars; P4 with very undulating ectoloph and narrow lingual face showing a deep sulcus; and M1-2 with less undulating ectoloph 
1

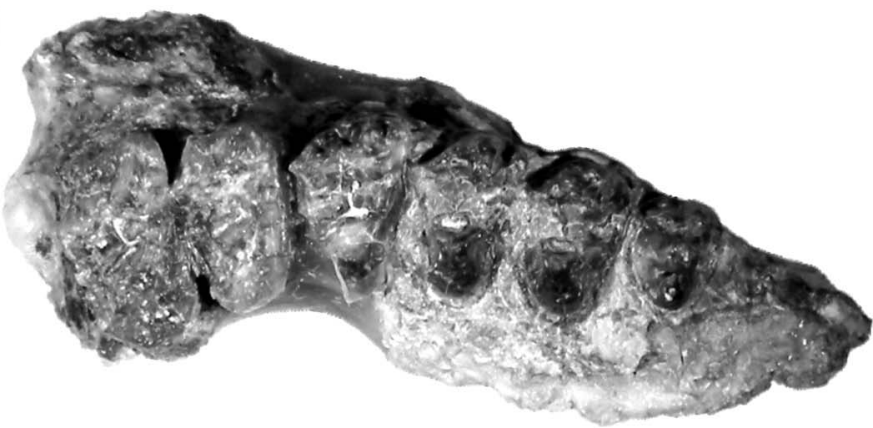

3

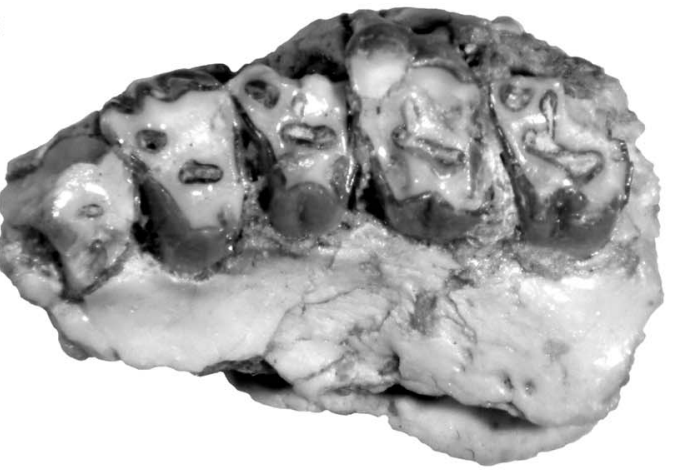

6
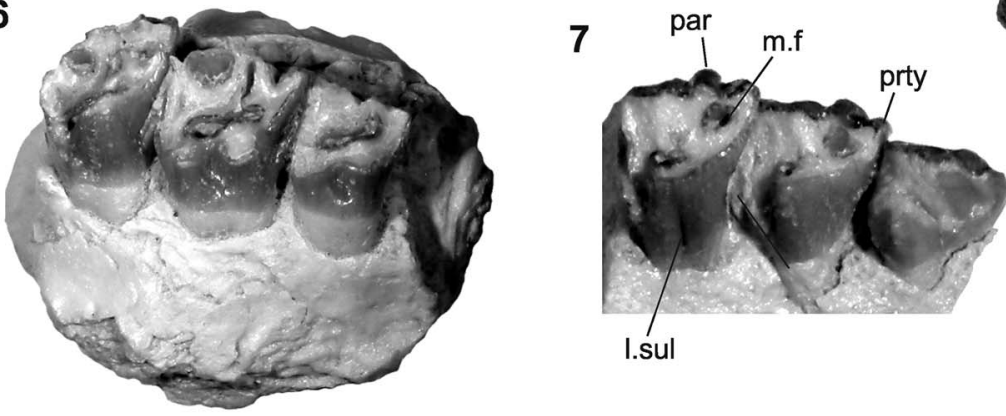

4 med. f.

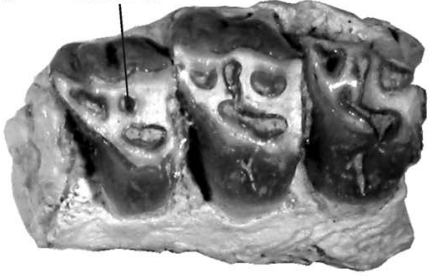

8
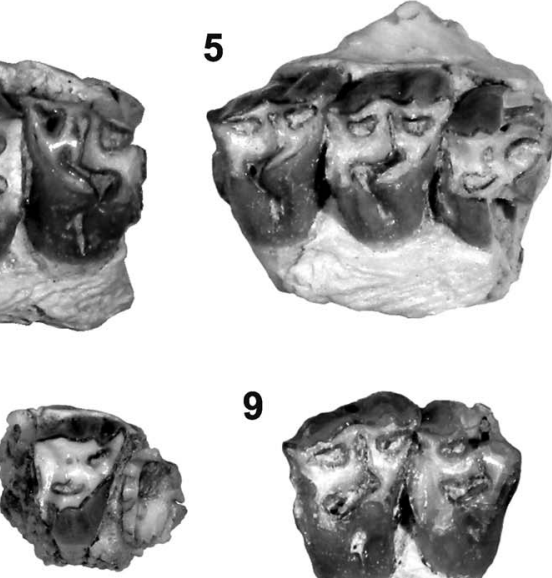

9
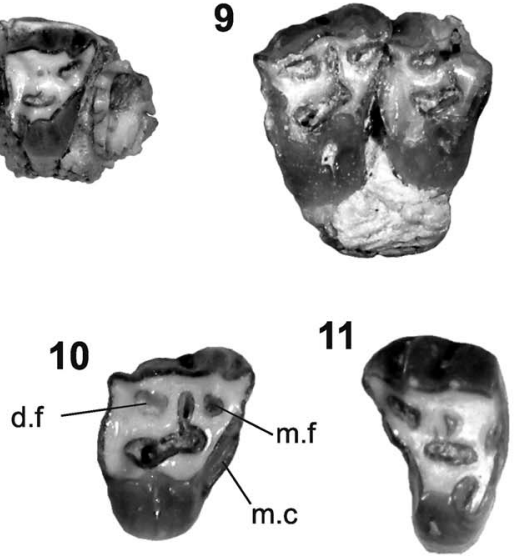

12

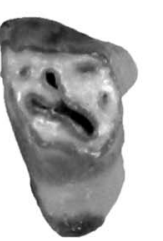

13

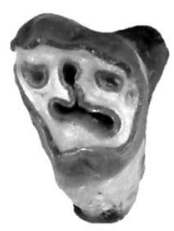

14
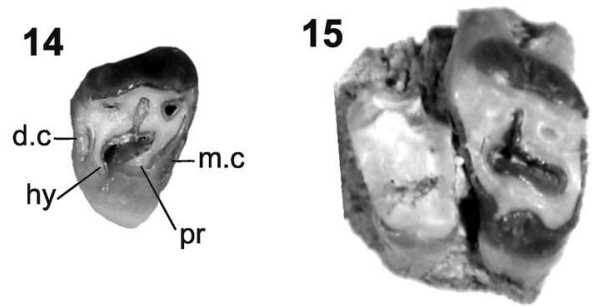

16

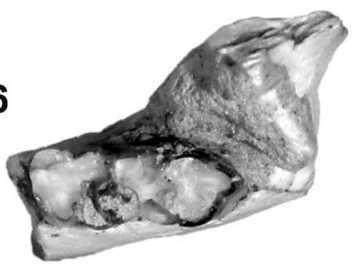

17

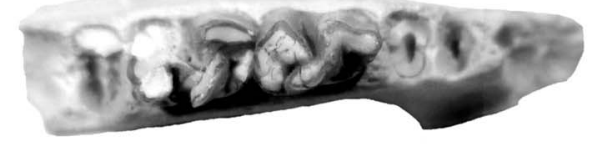

18
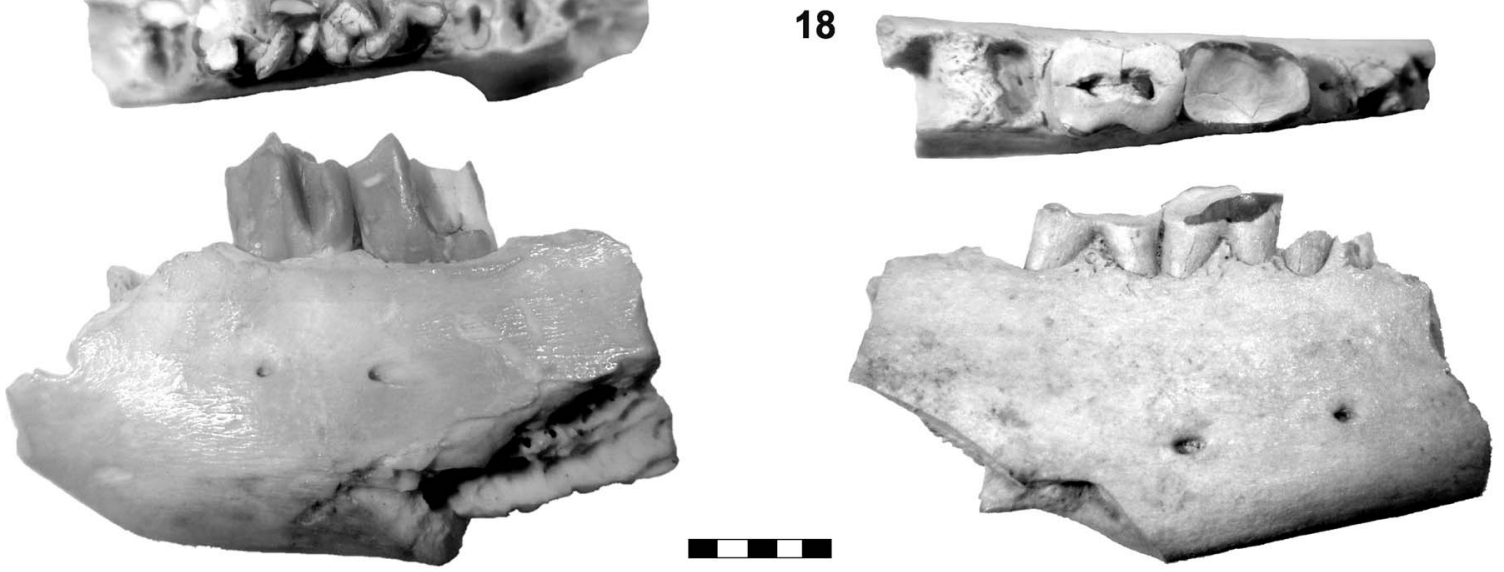
than $\mathrm{P} 4$, hypocone lingually more developed than the protocone and both lingually separated by a deep sulcus. MACN-A $10813 \mathrm{~b}$ is similar to MACN-A 10813a (Fig. 2.3) and MACN-A 10813c (Fig. 2.5). MACN-A 10813e (Fig. 2.7) shows very little wear; P2 has a low and reduced mesial cingulum and cannot be compared directly with MACN-A 10813a or MACN-A 10813c, but the premolars are similar to those of MACN-A $10813 \mathrm{~b}$ as P3 has a deep lingual sulcus and P4 a clearly undulating ectoloph and high distal cingulum. The same is observed in MACN-A 10813f and MACN-A 10813i, where the P4s are comparable to those of MACN-A 10813b. In turn, MACN-A 10813 d shows a more advanced stage of wear than MACN-A $10813 \mathrm{~b}$ (e.g., M2 has protocone and hypocone united by entoloph), while MACN-A 10813h has a more developed mesial cingulum than MACN-A 10813b. All specimens in lot MACN-A 10813 can be considered as several individuals of the same taxon in different ontogenetic stages.

Based on specimen MACN-A 10813b (Fig. 2.4), Simpson (1967b) considered Archaeopithecus rigidus as a senior synonym of Acropithecus tersus; he proposed the combination Acropithecus rigidus, and also included Archaeopithecus alternans in the genus Acropithecus. Simpson (1967b, p. 65) incorporated in the hypodigm of Acropithecus rigidus several specimens from the AMNH collection (such as AMNH FM 28782, AMNH FM 28884, AMNH FM 28895), as well as seven partial mandibles with teeth, around 150 identified isolated upper cheek teeth and around 150 identified isolated lower cheek teeth (with no number or description).

As stated by Simpson (1967b, p. 63-65), the differences between Acropithecus and Archaeopithecus were based mainly on P1-3: Acropithecus has asymmetrically triangular premolars, a P1 longer than wide and a P2 less transverse; in contrast, Archaeopithecus has more transverse, more symmetrical and less pronounced ectoloph in P1-3. Interestingly, Simpson described the P2 of Acropithecus based on nine individuals in different stages of wear and mentioned a vertical groove immediately anteroexternal to the protocone and a sinuous protoloph; he also mentioned a mesial cingulum on the $\mathrm{P} 2$, on three of $23 \mathrm{P} 3 \mathrm{~s}$, and on 12 of $26 \mathrm{P} 4 \mathrm{~s}$; when present, the cingulum is very weak, evidencing a high variability in this character. The same features (lingual sulcus, mesial cingulum, and sinuous ectolophe) are observed on the premolars of MACN-A 10816 (holotype of Archaeopithecus rogeri; Fig. 2.1); in addition, the dimensions of MACN-A 10813e (Fig. 2.7) are similar to those of MACN-A 10816, and differences in transverse and anteroposterior diameters are not significant between specimens (Table 1). This clearly demonstrates that both the specific differentiation between $A$. rogeri and $A$. rigidus proposed initially by Ameghino (1901) and the generic distinction between
Acropithecus and Archaeopithecus pointed out by Simpson (1967b) cannot be supported based on the dimensions and morphology presented here.

According to the MACN catalogue, the type specimen of Acropithecus tersus, MACN-A 10850 (Fig. 2.12-2.14), comes from Casamayoran levels of Patagonia. Lot MACN-A 10850 includes three upper molars, two left M3 (Fig. 2.12, 2.13) and one right M3 (Fig. 2.14), with disparity in wear stage and, hence, belonging to different individuals. Ameghino (1904, p. 204, fig. 231) figured the left M3s but identified them as M2-3 of the same individual. Simpson (1967b) considered the association incorrect and synonymized the name Acropithecus tersus with Archaeopithecus rogeri, despite of the type specimen of the latter (MACN-A 10816; Fig. 2.1) has no M3 preserved. The left M3s MACN-A 10850 (Fig. 2.12, 2.13) are very similar to each other; they have a very reduced mesial cingulum and their lingual sulcus is mesially placed; in turn, the right M3 MACN-A 10850 (Fig. 2.14) has less wear than the previous molars (the lingual valley is open, separating protocone from hypocone) and the mesial cingulum is more developed. The three molars have a trapezoidal outline and are comparable in morphology and size (Table 1) to the M3s of MACN-A 10813d (Fig. 2.6) and other specimens, such as AMNH FM 28782 (Fig. 3.3) and MMdP-M 727 (Fig. 4.1), so that that there is no enough evidence to consider a different species based only on these three upper molars (Table 1; Supplemental Data 3). Herein, indirect evidence (morphological and metrical similitudes between MACN-A 10850 and MACN-A 10813d, and between the latter and MACN-A 10816) allows establishing a comparison between Acropithecus tersus and Archaeopithecus rogeri, in agreement with the synonymy proposed by Simpson (1967b).

As mentioned before, Ameghino (1903) transferred Adpithecus plenus Ameghino, 1902 to the genus Acropithecus, establishing Acropithecus plenus. The specimen catalogued as the type of Adpithecus plenus has the number MACN-A 10851, which consists of a lot including a maxillary fragment with left M1-2 (here numbered MACN-A 10851a; Fig. 2.15) and a mandibular fragment with very worn right m2-3 (MACN-A 10851b; Fig. 2.16). Adpithecus plenus, however, was described based on upper dentition (Ameghino, 1902, p. 8), which implies that the specimen MACN-A 10851a is actually the holotype of this species. Strong evidence for this assumption is the metrics of M1 MACN-A 10851a (Table 1), which matches almost exactly with the dimensions provided by Ameghino $(5.0 \times 7.5 \mathrm{~mm})$. The mandibular fragment MACN-A $10851 \mathrm{~b}$ does not belong to the same individual and, therefore, it is not part of the holotype; it is probably a different taxon. Besides, MACN-A 10851a shows morphologic (Fig. 2.15) and metrical (Table 1) similitudes with

\footnotetext{
Figure 2. Archaeopithecus rogeri. (1) MACN-A 10816, holotype: maxillary fragment with right P1-M2, occlusal view; (2) MACN-A 10815, holotype of Archaeopithecus alternans: maxillary fragment with left M1-3, occlusal and lingual views; (3-11) MACN-A 10813, material catalogued as type of Acropithecus rigidus: (3) MACN-A 10813a, maxillary fragment with left P2-M2; (4) MACN-A 10813b, maxillary fragment with left P4-M2; (5) MACN-A 10813c, maxillary fragment with right P4-M2; (6) MACN-A 10813d, maxillary fragment with right M1-3; (7) MACN-A 10813e, maxillary fragment with right P1-3?; (8) MACN-A 10813f, maxillary fragment with right P4; (9) MACN-A 10813g, maxillary fragment with right M1-2; (10) MACN-A 10813h, right M1 or M2; (11) MACN-A 10813i, left P4; (12-14) MACN-A 10850, material catalogued as type of Acropithecus tersus: (12, 13) two left M3 and (14) right M3, not associated, occlusal and lingual views; (15) MACN-A 10851a, holotype of Acropithecus plenus: maxillary fragment with left M1-2, occlusal view; (16) MACNA 10851b, fragment with right m2-3, occlusal view; (17) MACN-A 10824a, holotype of Notopithecus fossulatus: mandible fragment with left p4-m1 and roots of p3 and m2, occlusal and labial views; (18) MACN-A 10824b, Notoungulata indet: mandible fragment with two extremely worn right teeth, occlusal and labial views. Abbreviations in the text. Scale bar is $5 \mathrm{~mm}$.
} 


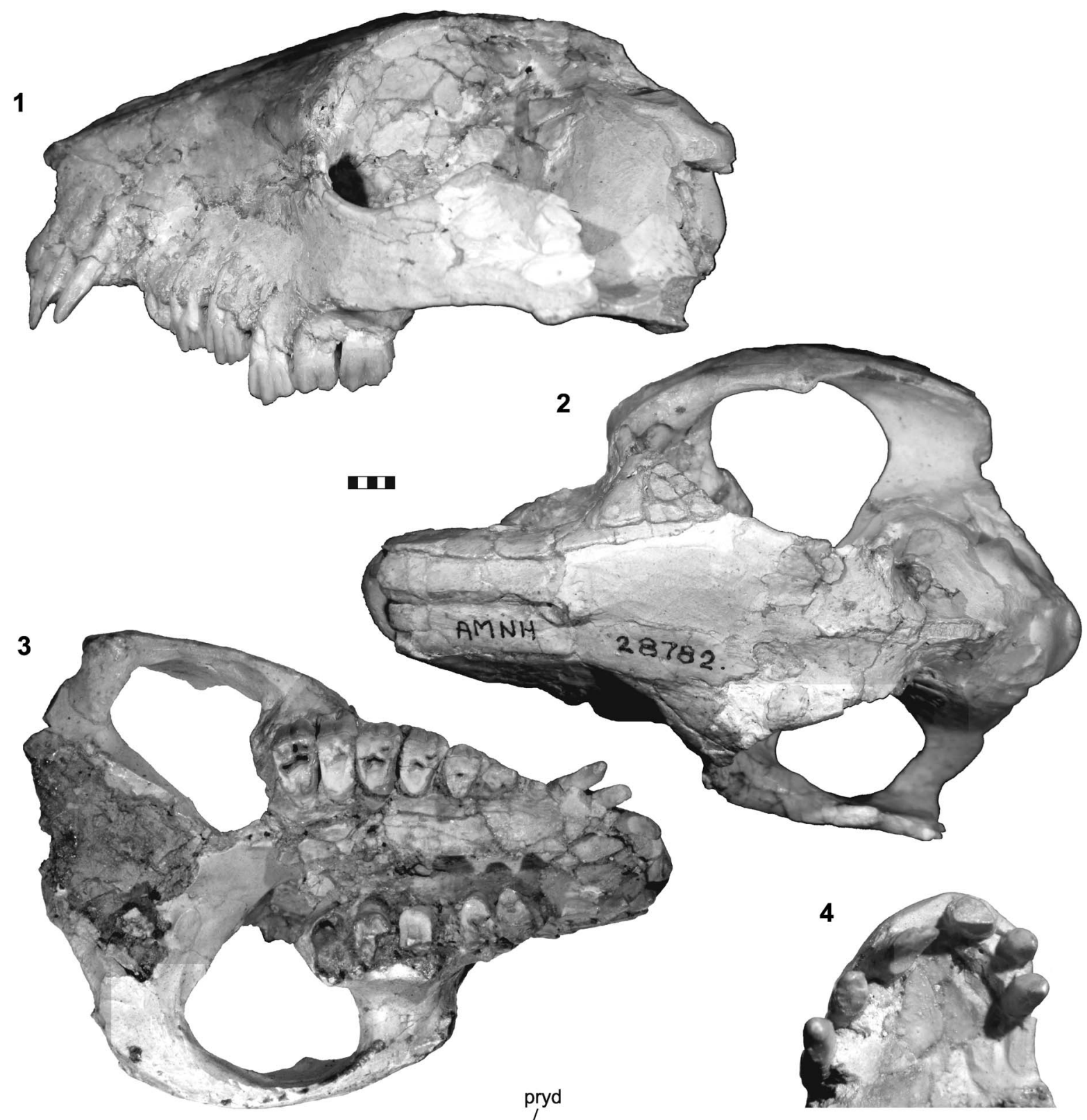

6
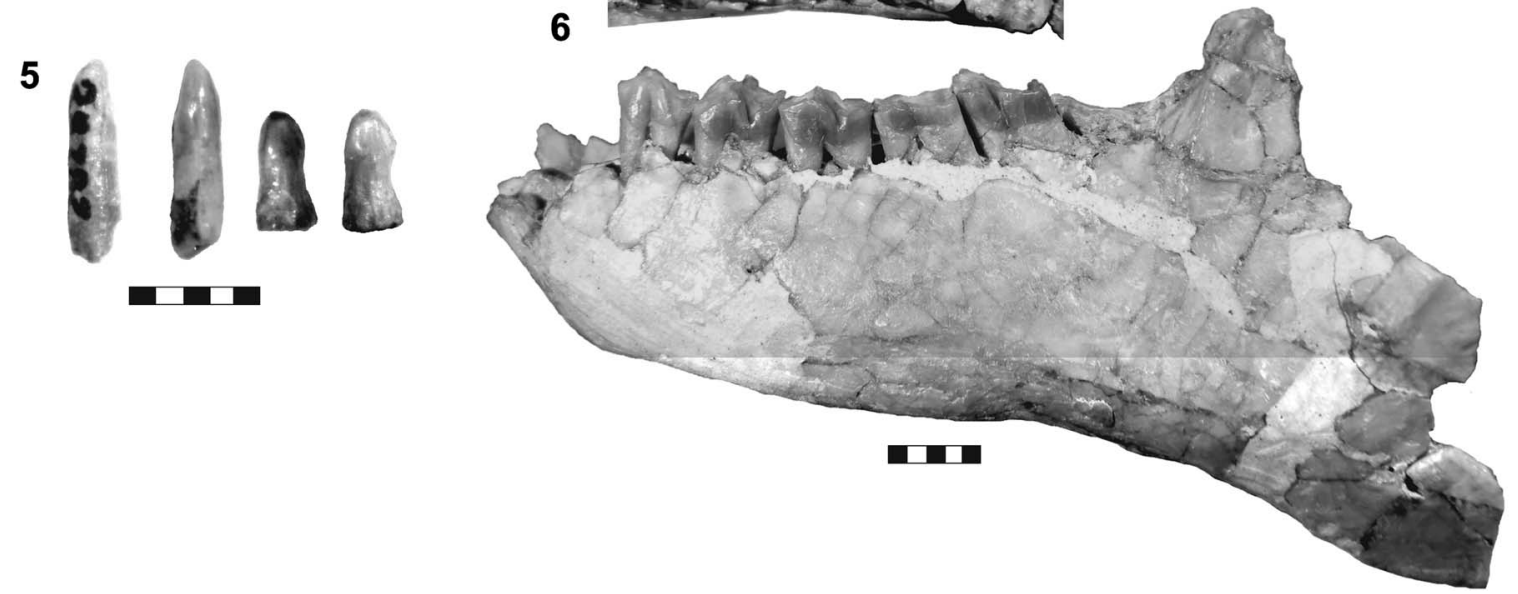

Figure 3. Skull and mandible AMNH FM 28782 (Acropithecus rigidus sensu Simpson, 1967b): (1) lateral view, (2) dorsal view, (3) ventral view, (4) detail of right I1-3 and left I1-3, occlusal view (not at scale); (5) isolated lowermost anterior teeth; (6) right dentary and detail of p2-m2, occlusal and labial views. Abbreviations in the text. Scale bars are $5 \mathrm{~mm}$. 
MACN-A 10816 (holotype of Archaeopithecus rogeri; Fig. 2.1), MACN-A 10815 (holotype of Archaeopithecus alternans) and MACN-A 10813b (lectotype of Archaeopithecus rigidus; Fig. 2.4), as well as with the maxilla AMNH FM 28782 (Fig. 3.3). In turn, MACN-A 10851b (Fig. 2.16) is very different from the associated mandible AMNH FM 28782 (Fig. 3.6) and other specimens with lower teeth (Fig. 4.17, 4.19-4.22). Actually, the smaller size of MACN-A $10851 \mathrm{~b}$ and some characteristics, such as straight protolophid and metalophid, longer paralophid and absence of hypoflexid in $\mathrm{m} 3$, make it resembles Notopithecus.

Simpson (1967b, p. 64) considered Acropithecus plenus a junior synonym of Archaeopithecus rogeri based on the similarity that he observed between both holotypes, MACN-A 10851a and MACN-A 10816, although he mentioned that the lingual sulcus on the M2 of A. rogeri (MACN-A 10816; Fig. 2.1) is stronger than that of Acropithecus plenus (MACN-A 10851a; Fig. 2.15). On this point, both M2s under discussion show a strong lingual sulcus, which is more evident in MACN-A 10816 due to its lesser wear in comparison with MACN-A 10851a, whose M1 is almost erased occlusally (Fig. 2.15). Thus, considering this evidence as well as the similarities between MACN-A 10851a (holotype Adpithecus plenus) and MACN-A 10816 (holotype of Archaeopithecus rogeri), two different species are not supported here (see below for priority).

Finally, the case of Archaeopithecus fossulatus deserves a special attention. Ameghino (1897) described Notopithecus fossulatus within Notopithecidae, but Simpson (1967b) transferred it to the genus Archaeopithecus in the Archaeopithecidae, establishing the combination A. fossulatus (Ameghino, 1897). It is important to note that Ameghino (1897, p. 18, figs. 6a-d) described the species based on a right mandibular fragment with p3-4 (according to his interpretation, but see below), which differs from Notopithecus adapinus Ameghino, 1897, in having a larger size (dimensions for every tooth were the same, $4 \mathrm{~mm} \times 3 \mathrm{~mm}$ ). The material catalogued as the type of Notopithecus fossulatus has the number MACN-A 10824 (Fig. 2.17, 2.18) and is a lot composed of three specimens. MACN-A 10824a is a mandibular fragment with left $\mathrm{p} 4-\mathrm{m} 1$ and roots of p3 and m2 (Fig. 2.17), which agrees with Ameghino's illustration (1897, fig. 6a-b); it was designated lectotype of $N$. fossulatus by Simpson (1967b), though he identified the teeth as p3-4. MACN-A 10824b (Fig. 2.18) is a mandibular fragment with two extremely worn right teeth (not figured by Ameghino, 1897), which Simpson (1967b, p. 64) described as p4-m1, not associated with MACN-A 10824a. Last, MACN-A 10824c is an isolated left P2, figured, but not described by Ameghino (1897, figs. 6c-d), and referred by Simpson (1967b) as uncertain P2 (not associated). Later, Vera (2012a) considered the specimen MACN-A $10824 \mathrm{c}$ as a P2 of the notopithecid Transpithecus obtentus Ameghino, 1901; thus, Notopithecus fossulatus became a synonym (in part) of $T$. obtentus.

Simpson (1967b, p. 64) pointed out that both mandible fragments (MACN-A 10824a and MACN-A 10824b) are practically indeterminable, and that they could be either Archaeopithecus rogeri or Acropithecus rigidus. He explained, on the one hand, that the lower premolars are morphologically identical to but shorter in length than the specimens assigned to Acropithecus rigidus housed at the AMNH. On the other hand, a direct comparison with the species of Archaeopithecus was impossible because no lower dentition is known for this genus (the only mandible described by Ameghino is lost, see above). Briefly, because Simpson (1967b) was not very confident in establishing synonymy, he proposed tentatively the combination ?Archaeopithecus fossulatus.

A recent revision and comparison of specimens MACN-A 10824a and MACN-A 10824b enable me to suggest a different, more conservative position. Firstly, both specimens do not correspond to the morphotype of the genus Notopithecus or any other member of the notopithecid group. MACN-A 10824a (Fig. 2.17) is very similar to AMNH FM 28705 and AMNH FM 28801, two specimens catalogued as Acropithecus rigidus; thus, it is grouped with the Archaeopithecidae. On the other hand, the extreme wear of specimen MACN-A 10824b (Fig. 2.18) has erased all features on the occlusal surface of $\mathrm{p} 4-\mathrm{m} 1$ to allow any comparison; although it could be considered Archaeopithecidae based on its association and similar size to MACN-A 10824a, it is here regarded as Notoungulata indet.

As a final point, with respect to more recent mentions of archaeopithecids, Cladera et al. (2004, p. 317) listed the presence of Archaeopithecus? sp. nov. in Gran Hondonada (Chubut Province), a locality referred to the Mustersan SALMA (late Eocene); however, the authors did not provide either a catalogue number or a figure of these specimens. Tejedor et al. (2009) referred to Archaeopithecus cf. A. rogeri some maxillary and mandibular remains and isolated teeth from the Paso del Sapo fauna (late early Eocene, Woodburne et al., 2014a) represented in La Barda and Laguna Fría localities (west of Chubut Province). More recently, some remains from Las Violetas locality (Chubut Province) were assigned as Acropithecus rigidus (Gelfo et al., 2010; Bauzá et al., 2016), which were recovered from a sequence overlaying Las Violetas Formation (Río Chico Group); according to these authors, this faunal assemblage is early Eocene in age (Ypresian) and shows affinities with those of the Paleocene Itaboraian and 'Sapoan' biochrons (Woodburne et al., 2014b and references therein).

\section{Systematic paleontology}

Anatomical and dimensional abbreviations.-AP, antero-posterior; C/c, upper/lower canine; c.f, central fossette; c.ftd, central fossettid; c.o, cristid oblique; entyd, entostylid; d.c, distal cingulum; d.ftd, distal fossettid; end, entoconid; $\mathrm{H}$, height; hy, hypocone; hylfd, hypolophid; I/i, upper/lower incisor; L, length; LLD, labiolingual diameter; lb.sul, labial sulcus; M/m, upper/ lower molar; Mc, metacarpal; m.c, mesial cingulum; m.cgd, mesial cingulid; MDD, mesiodistal diameter; m.f, mesial fossette; med.f, medial fossette; mtd, metaconid; P/p, upper/ lower premolar; par, paracone; prty, parastyle; pr, protocone; pryd, protostylid; T, transversal; W, width.

Order Notoungulata Roth, 1903

Family Archaeopithecidae Ameghino, 1897

Genus Archaeopithecus Ameghino, 1897

Type species._Archaeopithecus rogeri Ameghino, 1897. 


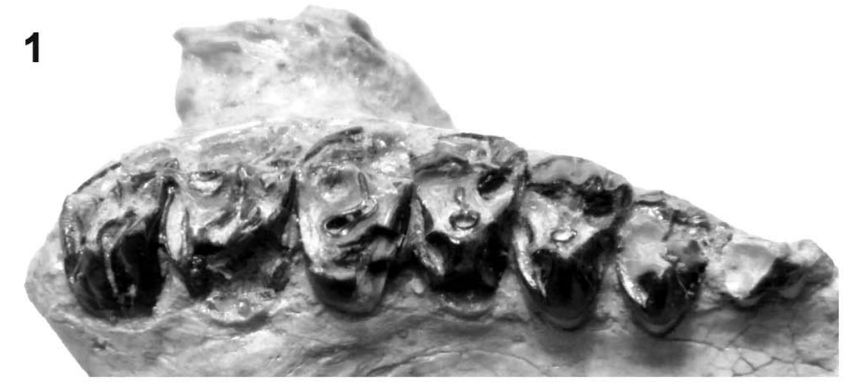

2

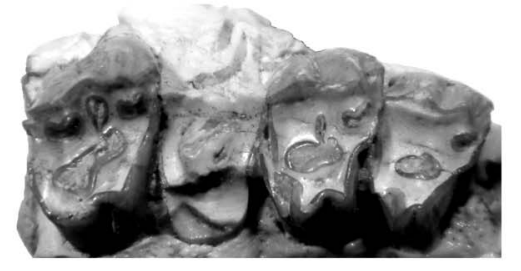

3
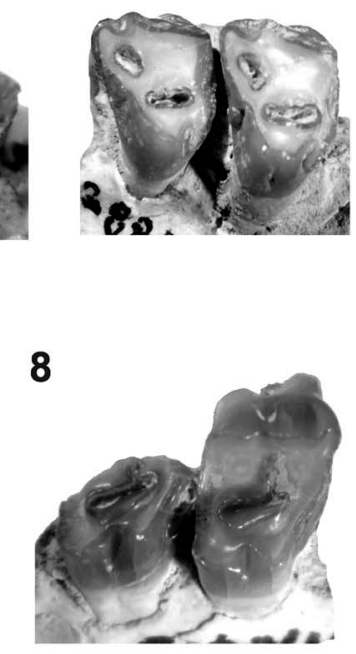
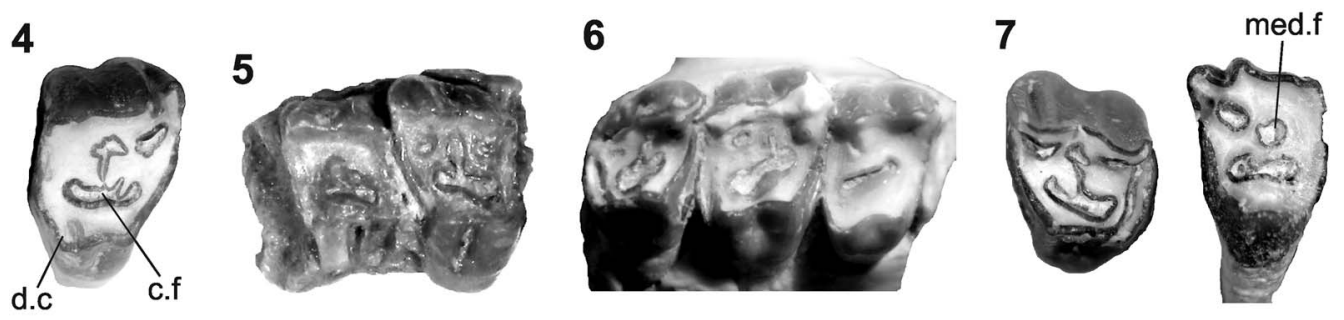

9

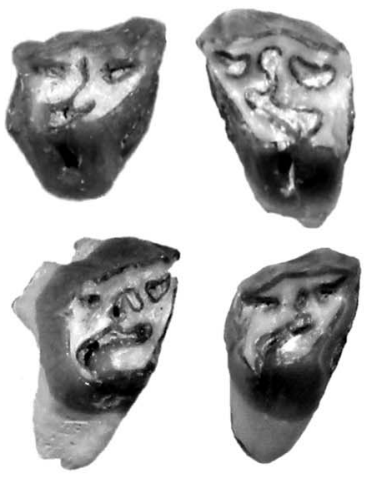

14

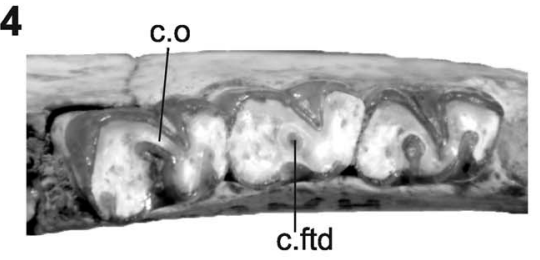

15

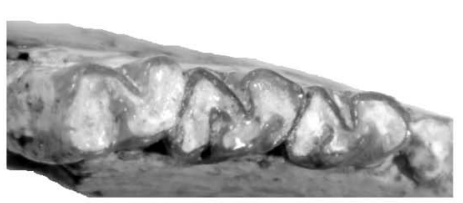

20

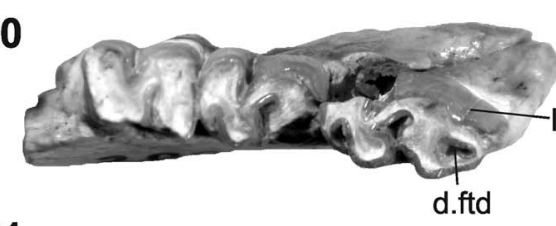

21

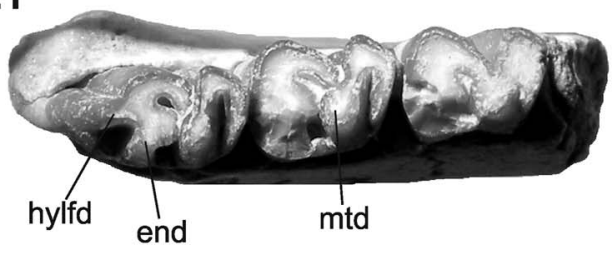

16

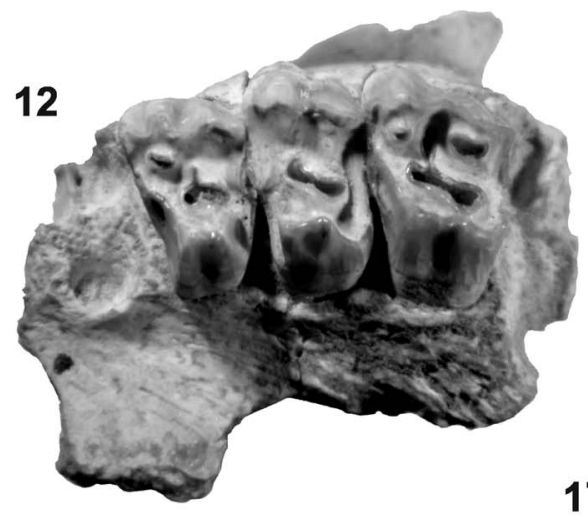

13

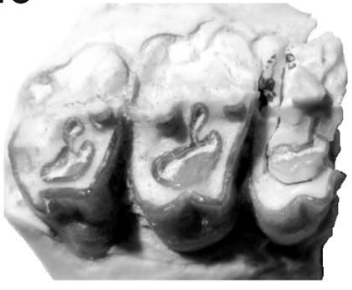

17

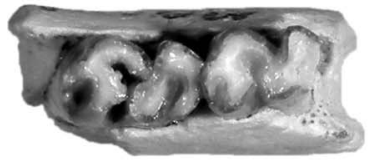

hylfd entyd mtd entyd m.cgd
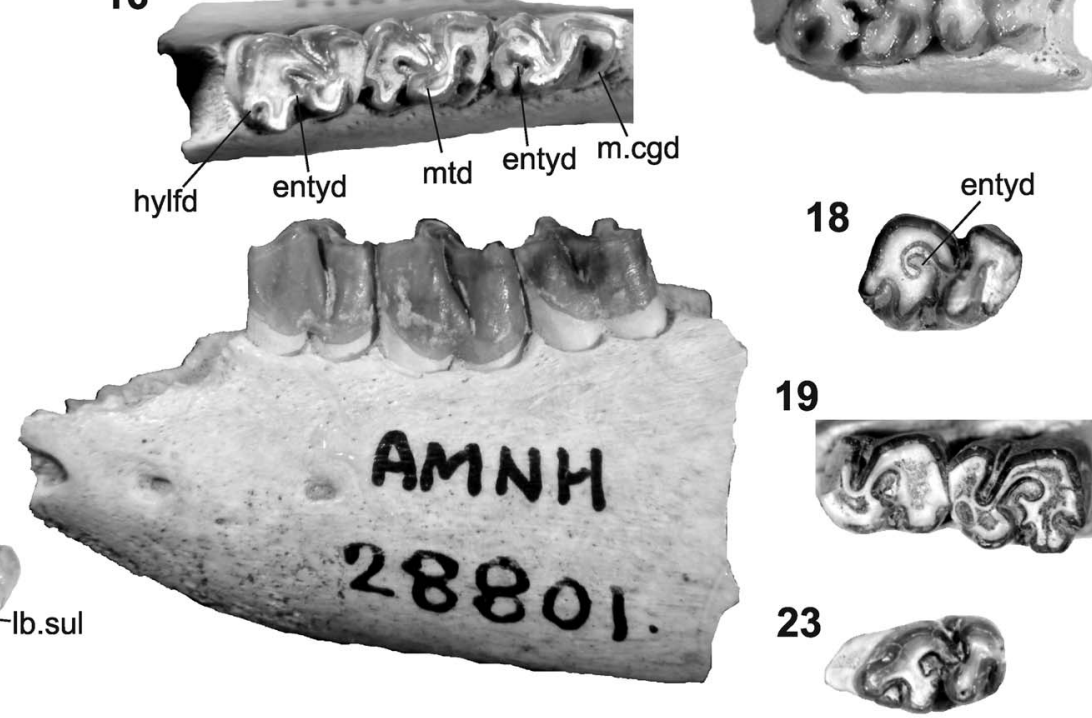

19

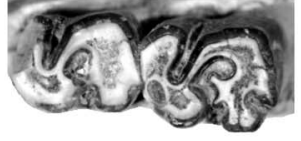

23

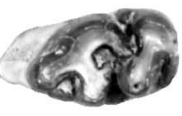


Diagnosis.-Archaeopithecus differ from Notopithecus in having a taller cranium and longer rostrum, moderate-sized tympanic bullae, not reduced jugal and external expansion of lacrimal; the symphysis is very short and wide and the mandibular bone is robust. The dentition is complete, rooted and brachydont, but relatively higher-crowned than in other brachydont early notoungulates, such as notopithecids and oldfieldthomasiids. Archaeopithecus differs from notopithecids, oldfieldthomasiids and interatheres in having conical upper and lower incisors and canines, and short diastemata between these teeth and P1. P1 is not reduced and has parastyle, differing from notopithecids, Notostylops and Oldfieldthomasia. P/p1 are not overlapped by $\mathrm{C} / \mathrm{c}$ and $\mathrm{P} / \mathrm{p} 2$ and lowers molars with a reduced paralophid, differing from typotherians. A lingual sulcus divides protocone in two lobes in P3-4, differing from Notopithecus and Antepithecus. Upper molars are approximately square in young specimens (TD MDD), but the transverse diameter increases towards the base, becoming rectangular (TD > MDD) when worn. M1-M2 have hypocone lingually more developed than the protocone (like in Transpithecus). M3 has hypocone, unlike notopithecids, oldfieldthomasiids and other Eocene notoungulates. P4-M3 are characterized by having a central fossette with a mesiodistally elongated section and a narrow labial projection, which becomes an isolated 'third labial' fossette with wear (like molars of Archaeohyrax suniensis). Lower incisors have non-procumbent implantation, unlike Notostylops, and there is no groove in i1, differing from notopithecids. p2-4 have a welldeveloped protostylid fold, unlike Notopithecus, Antepithecus, Notostylops and oldfieldthomasiids. Archaeopithecus has a well-developed postmetacristid on p3-4, a feature shared by notopithecids, but not by oldfieldthomasiids, hericosborniids and notostylopids. Archaeopithecus contrasts with other Eocene notougulates by having lower molars with a well-developed entostylid (shared with Pleurostylodon) and a deep hypoflexid on talonid of m3 (except Henricosbornia).

Remarks.—Diagnosis emended from Ameghino (1897) and Simpson (1967b).

\section{Archaeopithecus rogeri Ameghino, 1897} Figures 2-5

1897 Notopithecus fossulatus Ameghino, p. 18, figs. 6a-d.

1901 Archaeopithecus alternans Ameghino, p. 359.

1901 Archaeopithecus rigidus Ameghino, p. 359.

1902 Adpithecus plenus Ameghino, p. 8.

1903 Acropithecus tersus Ameghino, p. 194.

1903 Acropithecus plenus; Ameghino, p. 195.
1904 Archaeopithecus rigidus; Ameghino, figs. 403-405.

1904 Acropithecus tersus; Ameghino, figs. 231, 280.

1967b Archaeopithecus fossulatus; Simpson, p. 64 (part). 1967b Acropithecus rigidus; Simpson, p. 65.

Holotype.-MACN-A 10816, maxillary fragment with right P1-M2 (Fig. 2.1). This specimen lacks locality data, but it probably comes from south of Colhué Huapi lake, Chubut Province (Simpson, 1967b).

Diagnosis.—As for the genus, by monotypy.

Materials.-Materials are listed below by locality.

Bajo Palangana.-MGP 29056, left $\mathrm{m} 3$ and right $\mathrm{m} 1$ ?; MGP 31657, right $\mathrm{m} 2$ ?; MGP 31658, right dentary $\mathrm{m} 2-3$ and left M3; MGP 31663, left maxilla with broken M1-2; MGP 31717, right maxilla M2 (broken); MGP 31718, right upper molar, broken; MGP 31719, left lower molar; MGP 31720, right lower molar; MGP 31727, right m3; MGP 31729, right M1?; MGP 31753, right P3?; MGP 31759, left m2?; MGP 31763, left upper premolar; MGP 31767, right m1?; MGP 31768, right molar; MGP 31769, left P3?; MGP 31777, left P3?; MLP 34V-22-7, right M2?; MLP 61-VIII-3-145, left maxilla P2-3?; MLP 61-VIII-3-146, left maxilla P3-M1; MLP 61-VIII-3-148, left maxilla P2-M2; MLP 61-VIII-3-176, right maxilla P4-M2; MLP 61-VIII-3-177, left maxilla P4-M2.

Bahía Solano.-MGP 31595, right M2?; MGP 31596, right m2?; MGP 31597, left m1?; MGP 31598, right m2?; MGP 31599, left m3; MGP 31600, left P3; MGP 31601, left m2?; MGP 31602, recently erupted left lower molar; MGP 31603, left m3; MGP 31604, left talonid m3; MGP 31605, broken right upper premolar; MGP 31606, left P3?; MGP 31607, right m1?.

Northeast Cabeza Blanca.-AMNH FM 28824, right maxilla P4-M2; AMNH FM 28871, isolated left M1?, M3?, two right upper molars; AMNH FM 28872, isolated left $\mathrm{p} 4$ and $\mathrm{m} 3$, and right molar; MLP 79-I-17-10, right maxilla P4-M2; MLP 79-I-17-12, right maxilla P3-M2; MLP 79-I-17-20, right maxilla P4-M2; MLP 79-I-17-22, right maxilla P3-M3; MLP 79-I-17-36, left P3?; MLP 79-I-17-37, left P4?; MLP 79-I17-41, left maxilla M1-2; MLP 79-I-17-48, left maxilla P4-M2; MLP 79-I-17-50, left maxilla P4-M2.

Campo Muriette.-MLP 61-VIII-3-425 to 446, 3 upper premolars, 8 upper molars, 3 lower premolars, 7 lower molars; MLP 66-V-10-4, left M2?; MLP 66-V-10-19, right m3.

Cañadón Hondo.- AMNH FM 28534, right maxilla M1M2; MACN-A 10824a, left dentary $\mathrm{p} 4-\mathrm{m} 1$ and rows $\mathrm{p} 3$ and m2; MMdP-M 727, right maxilla P1-M3.

Cañadón Blanco.-MLP 12-1529, left m2?.

\footnotetext{
Figure 4. Archaeopithecus rogeri. (1) MMdP-M 727, maxillary fragment with right P1-M3, occlusal view; (2) MNH CAS 739, maxillary fragment with right P3-M2, occlusal view; (3) AMNH FM 28841, maxillary fragment with left P2-3?, occlusal view; (4) MLP 93-XI-22-16a, right P4, occlusal view; (5) MACNPV 11237, maxillary fragment with left M1-2, occlusal view; (6) MGP 31362, maxillary fragment with right M1-3, occlusal view; (7) MLP 93-XI-22-3, left P4 and upper molar, occlusal view; (8) AMNH FM 28534, maxillary fragment with right M1-M2, occlusal view; (9) MACN-A 10831, right upper molar, left M1? and two right M3, occlusal view; (10) MGP 31595, right M2?, occlusal view; (11) MACN-A 10847, left M3, occlusal view; (12) AMNH 28827, maxillary fragment with left P4-M2, occlusal view; (13) MPEF 1580b, maxillary fragment with M1-3, occlusal view; (14) AMNH FM 28840, dentary with left p4-m2, occlusal view; (15) AMNH FM 28705, dentary with left p3-m1 and right p2-3, occlusal view; (16) AMNH FM 28801, dentary with left p3-m1, occlusal and labial views; (17) MACN-A 10841c, dentary with left m1-2, occlusal view; (18) MLP 93-XI-22-16b, left lower molar, occlusal view; (19) MLP 93-XI-22-3a, dentary with right m1-2, occlusal view; (20) AMNH FM 28884d, dentary with right m1-3, occlusal view; (21) PVL 163, dentary with left m1-3, occlusal view; (22) MGP 29028, dentary with right m2-3, occlusal view; (23) MGP 31599, left m3; (24) MLP 66-V-10-19, dentary with right m3, occlusal view. Abbreviations in the text. Scale bar is $5 \mathrm{~mm}$.
} 

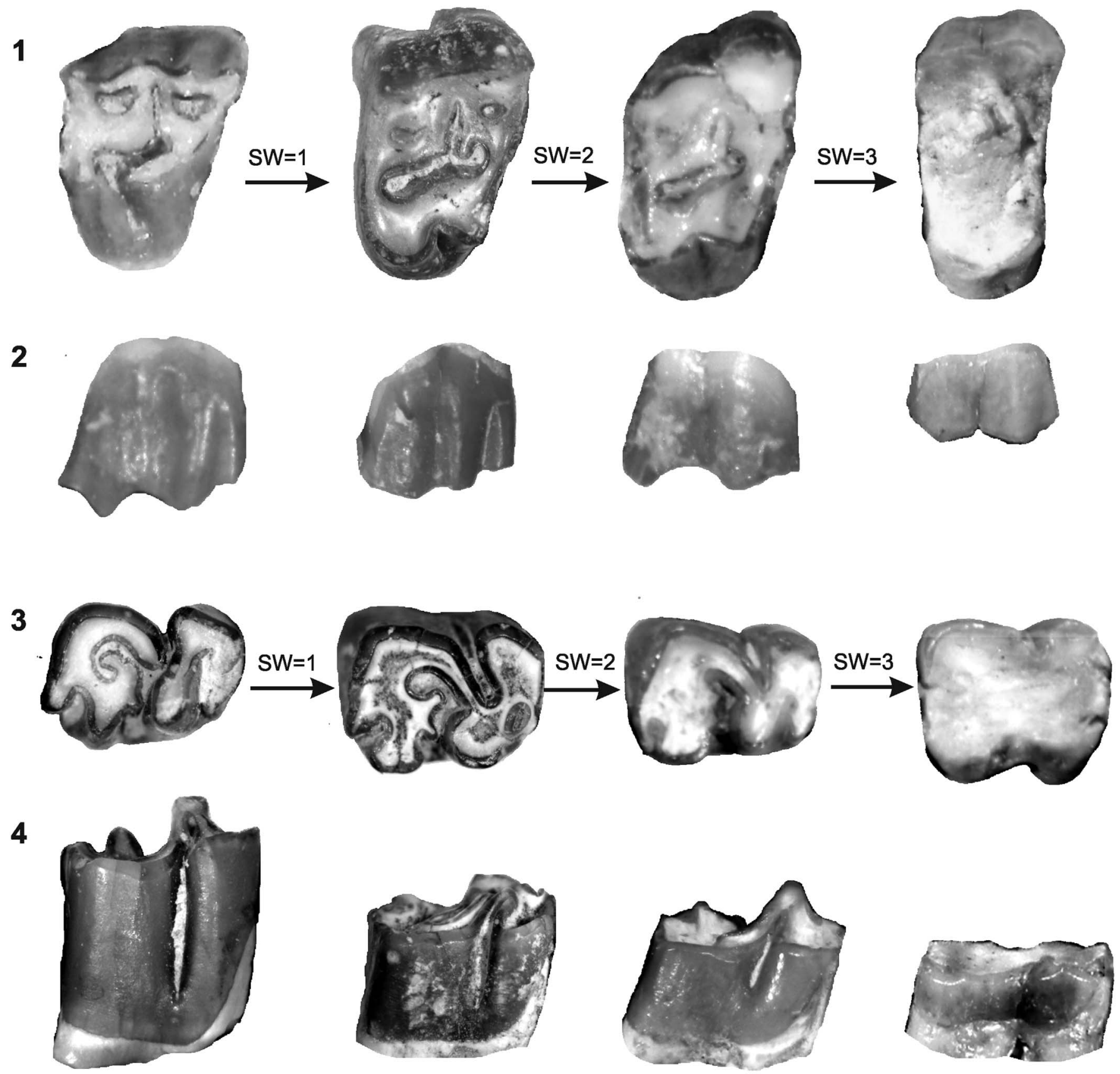

Figure 5. Morphological variation of $\mathrm{M} 1$ and $\mathrm{m} 1$ of Archaeopithecus rogeri throughout ontogeny: occlusal $(\mathbf{1}, \mathbf{3})$ and labial $(\mathbf{2}, \mathbf{4})$ views. From left to right, $(\mathbf{1}$, 2) M1: MACN-A 10813c, MLP 93-XI-22-3b, MACN-A 10813a, AMNH FM 28782; (3, 4) m1: MLP 93-XI-22-16b, MLP 93-XI-22-3a, AMNH FM 28840 and AMNH FM 28782. SW = stage of wear: 1, little; 2, middle; 3, heavy. From SW 1 to 3: occlusal surface becomes featureless and crown diminishes in height; M1 shortens and $\mathrm{m} 1$ widens (see text for details).

Colhué Huapi.-AMNH FM 144694, left m3; MACN-A $10833 \mathrm{c}$, right M2; MACN-A 10841c, left dentary m1-2; MACNPv 11237, left maxilla M1-2; MACN-Pv 12842, left maxilla M1-3.

Cerro Solo.-MPEF-PV 1570, left M2 and M3, right P4 and M1; MPEF-PV 1580: a, right maxilla P4-M2; b, right maxilla M1-3; c, left maxilla P4.

Cañadón Vaca.-AMNH FM 28534, right maxilla M1M2; AMNH FM 28705, left dentary p3-m1 and right p2-3; AMNH FM 28782, skull with left I1-3, P1 (broken), P2-M2, and right broken I1-3, P3-4, M1 and M3; AMNH FM 28801, left dentary p3-m1; AMNH FM 28803, left dentary p4-m2; AMNH FM 28804, right dentary p3-4; AMNH FM 28805, right dentary with talonid of $\mathrm{m} 1$ and erupting $\mathrm{m} 2$; AMNH FM 28827, left maxilla P4-M2; AMNH FM 28840, left dentary p4-m2; AMNH FM 28841, left maxilla P2-3?; AMNH FM 28842, left dentary p3-4; AMNH FM 28868, right maxilla P2-M1; AMNH FM 28884: a, right maxilla M1-3; b, left maxilla M1 (broken)-M2; c, left maxilla P2-3 and broken P4-M2; d, right dentary m1-3; AMNH FM 28895, right 
maxilla P3-4; right Mc II-III, Mc IV?, left ulna, fragment of phalanx; AMNH FM 144693, right dentary p4-m1; AMNH FM 144695, right maxilla P4-M2; AMNH FM 144696, right maxilla M2-3; AMNH FM 144688, left dentary p4-m1; AMNH FM 144689, right dentary m2-3; AMNH FM 144690, left m1; AMNH FM 144691, right p3?; AMNH FM 144692, isolated and associated right M1, M2 and M3; AMNH FM 144693, right dentary p4-m1; AMNH FM 144694, left m3; AMNH FM 144695, right maxilla P4-M2; AMNH FM 144696, right maxilla M2-3; MGP 29028, right dentary m2-3; MLP 75-II-3-19, left P4; MLP 75-II-3-20, left m1 or m2; PVL 162, left dentary p4-m1; PVL 163, left dentary m1-3; PVL 165, left dentary p4-m1; PVL 166, right dentary m1-2; PVL 167, right p4, alveolus c and i3; PVL 199, right p4?; PVL 210, right M2?; PVL 232, left m1?; PVL 242, left P3?.

El Pajarito.-MLP 66-V-9-16, right P4?.

Lomas Blancas.-AMNH FM 28886, right P4?.

Las Cascadas.-MLP 93-XI-22-3, 22 lower teeth and 38 upper teeth, isolated; MLP 93-XI-22-16, 7 lower teeth and 12 upper teeth.

Oeste Río Chico (Ameghino's locality).-MACN-A 10813: a, left maxilla P2-M2; b, left maxilla P4-M2; c, right maxilla P4-M2; d, right maxilla M1-3; e, right maxilla P1-3; f, right maxilla P4; g, left maxilla M1-2; h, right M1?; i, left P4; MACN-A 10815, left maxilla M1-3; MACN-A 10831, right upper molar, left M1? and two right M3.

Pico Salamanca.-MGP 31362, right maxilla M1-3.

No locality data.-AMNH FM 15902c, right maxilla P4M1; MACN-A 10816, right maxilla P1-M2; MACN-A 10843, left lower molar; MACN-A 10847, left M3; MACN-A 10850, a-b) two left M3; c) right M3; MACN-A 10851a, left maxilla M1-2; MNHN-CAS 739, right maxilla P3-M2; MNHN-CAS 741, left m1; MNHN-CAS 751, right maxilla P4-M2.

Occurrence.-Las Flores Formation (?56-47 Myr, early middle Eocene; Krause et al., 2017) and Sarmiento Formation (Cañadón Vaca Member, 45-42 Myr, and Gran Barranca Member, 41.7-38.45 Myr, middle Eocene; Ré et al., 2010; Dunn et al., 2013; Bellosi and Krause, 2014; Krause et al., 2017). The fossiliferous localities with archaeopithecids are geographically located in Chubut Province, Argentina (Figure 1).

Description.-The following description for the cranium is based on specimen AMNH FM 28782 (Fig. 3.1-3.6), an adult individual with associated skull and mandible and much worn dentition; although partially restored, it is the most complete individual known for archaeopithecids.

As regards cranium size, the rostrum is short and high, but the cranium is taller and the rostrum longer and taller than in Notopithecus (MACN-A 10787, MACN-A 10790); the dorsal profile rises backwards. The maxillary bone is concave on its rostral portion, in front of the orbit (Fig. 3.1). The infraorbital foramen is circular and large, placed above the P4 level. The orbits, posteriorly open, are very large in relation to the skull; their most anterior border is at M1-2 level, just behind the infraorbital foramen (Fig. 3.1, 3.2). Nasals are rectangular, narrow and long. The zygomatic arches are laterally high and apparently (by restoration) much expanded in dorsal view (Fig. 3.1). In ventral view, the most anterior part of the premaxillaries is semi-circular and its width increases slightly from
I to P1 level; posteriorly, the palate is not significantly wider than the premaxillaries (Fig. 3.3, 3.4). Simpson (1967b, p. 61) noted that the jugal bone forms the external and anterior parts of the zygoma, continuing towards the lacrimal as a narrow splint, both different features from oldfieldthomasiids and notopithecids. Unfortunately, the poor preservation of AMNH FM 28782 does not allow differentiating main bones around orbital borders and defining the real extension of the lacrimal. The tympanic bullae are moderately sized in relation to cranium size, differing from other Eocene notoungulates such as Notopithecus, Oldfieldthomasia, and Colbertia.

The mandibular bone is robust; its height increases gradually backwards, from p2 $(\mathrm{H}=10.1 \mathrm{~mm})$ to $\mathrm{m} 2$ $(\mathrm{H}=15.1 \mathrm{~mm})$. The inferior border is convex up to $\mathrm{m} 2-3$ level, where there is a concavity, and after this point the height increases significantly (Fig. 3.6). The symphysis is very short and wide; its posterior border is at p2-3 level. There is a labial foramen below $\mathrm{p} 2$ and another one below talonid of $\mathrm{p} 3$.

Concerning the teeth, Archaeopithecus has a complete, rooted, brachydont (Fig. 3.3), but relatively higher-crowned dentition than other brachydont early notoungulates, such as notopithecids and oldfieldthomasiids. The enamel is continuous around the crown. Cementum is absent. The premolar series is longer than molar series, as in notopithecids; this ratio is characteristic of browser artiodactyls (Mendoza et al., 2002). No deciduous dentition was identified with certainly among the sample, probably because most of the sample corresponds to isolated teeth; thus, the following description refers to permanent teeth.

The morphology and size of archaeopithecid teeth are variable throughout ontogeny (Fig. 5.1-5.4), which led Ameghino to originally consider the presence of distinct species. The present revision and comparison of many archaeopithecid specimens permit establishing a wide intraspecific variation rather than interspecific differences, which was likewise observed in archaeohyracids (Croft et al., 2003; Billet et al., 2009; Cerdeño et al., 2010) and other notoungulate groups (Francis, 1960; Madden, 1997; Billet et al., 2008; Cerdeño et al., 2008). Indeed, Simpson (1967b) also recognized a highly variable morphology on crown pattern and dimensions in the archaeopithecid teeth samples he studied, such as the extremely variable mesial cingulum in premolars and molars. In Archaeopithecus, the upper teeth (mainly molars) are labiolingually narrow at occlusal level $(\mathrm{TD} \approx \mathrm{MDD})$, but the transverse diameter increases to the base, modifying the dimensions on the tooth (TD > MDD). Another peculiarity is that the presence of mesial cingulum and the lingual and mesial sulci are variable in the upper dentition of archaeopithecids.

Upper dentition.-The I1-3 of AMNH FM 28782 are cylindrical in outline (Fig. 3.4). I1 is the greatest incisor $(2.6 \times 2.4 \mathrm{~mm})$ and differs from the other incisors in having a labiolingualy flattened tip and a lingual wear facet; I2 $(2.0 \times 2.2 \mathrm{~mm})$ is a bit less compressed than I1 and the wear facet is less developed; I3 $(2.4 \times 2.0 \mathrm{~mm})$ is conic, pointed, and has two smooth facets on the mesial and distal sides. The canine in AMNH FM 28782 is broken at alveolar level, but the preserved crown fragment indicates a cylindrical tooth, with approximately the same diameter as I3. There are short diastemata 
separating incisors and canine, and between the canine and first premolar. Conic-shaped incisors and canine and the presence of diastemata distinguish Archaeopithecus from notopithecids, oldfieldthomasiids, and interatheres.

From P1 to P4 (Figs. 2.1, 3.3, 4.1), the series is premolariform, clearly distinguished from molars (see below). As a whole, the distal cingulum is high, wide, and well developed throughout the face, and it fuses with the metaloph in muchworn teeth; the mesial cingulum can be absent (Fig. 4.1, 4.3) or, when present, it is very narrow, near the base of the crown (Fig. 2.1); both cingula descend lingually. The parastyle, paracone, and metacone folds form a very undulate ectoloph and delimit deep labial sulci. There are mesiolabial and central fossettes in all premolars; on P1-2 the central fossette is small and circular, but on P3-4 it also has a labial portion that forms an isolated mediolabial fossette in worn teeth. A distolabial fossette was only observed in P4. The mesial and distal borders of P2-4 are undulate.

P1 and P2 (Figs. 2.1, 4.1) are triangular in outline, with conical protocone, centrally placed. They lack a lingual sulcus; instead, there is a sulcus in the middle of the mesial face, as in Transpithecus (Vera, 2012a), connecting to the central fossette on unworn teeth (Fig. 2.7). P1 is much narrower than P2 (Table 1), but the difference is not so significant between P2 and P3-4; P1 has a narrow and mesiodistally enlarged central fossette (Fig. 2.7) and a parastyle fold, in contrast to other notoungulates (e.g., Notopithecus, Colbertia) in which the P1 is much reduced or canine-like. In addition, P1 is non-overlapping by $\mathrm{C}$ and $\mathrm{P} 2$ (Fig. 3.3), differing from typotherians.

P3 is very similar to P1-2, but differs in having a lingual sulcus dividing the protocone column in two lobes (Figs. 2.7, 4.2), although in some cases, the lingual sulcus is absent (Figs. $2.1,4.1)$. A smooth sulcus in the mesial face is also observed in some specimens (Fig. 2.7).

P4 has a wider protocone than P3, lacks the characteristic triangular shape of the preceding premolars, and its mesial face can be singularly concave (Fig. 2.3, 2.11). The lingual sulcus is deep, forming two well-folded (Fig. 4.2) or softly folded (Figs. 2.4, 3.3) columns. In AMNH FM 28841, the paracone and metacone folds are not as undulate as in other specimens (Fig. 2.7). There are mesio- and distolabial fossettes, the latter being the shallowest and the first one to disappear. The central fossette can be circular or elongated and has a narrow labial extension; in some cases, there are internal crests in the central fossette and the mesial extension can be also variable in shape (Fig. 4.4).

As the wear advances in P2-4, the metaloph starts to connect with the distal cingulum at a middle point (Fig. 4.1, 4.2), forming two small pits, lingually and labially to the union; the lingual pit, just posterior to the protocone, is deeper than the labial pit and becomes a shallow fossette when worn (Fig. 2.11). In a very old individual (AMNH FM 28782; Fig. 3.3), M1 shows only the central fossette, while P2 and P3 also have a mesial fossette.

Compared with the premolars, the molars are squared or rectangular in outline, depending on the wear stage. M1 and M2 are very similar to each other, and it is difficult to identify them among isolated teeth. Unworn or very little worn molars have the central valley completely open on the lingual face and separating protocone from metacone ( $\mathrm{SW}=1$ in Fig. 5.1) When wear increases, these lingual cones fuse through a crest (entoloph), isolating the central fossette, and a sulcus on the lingual face is formed, which differentiates protocone and metacone columns ( $\mathrm{SW}=2$ in Fig. 5.1). This peculiarity is shared with some notopithecids (Vera, 2012a, 2012b; Vera and Cerdeño, 2014). On P4 and molars, the central fossette is mesiodistally elongated and has a narrow labial projection, which extends from the most anterior part of the central fossette in the M1 and from the middle part on M2 and M3 (Fig. 4.1). This labial projection becomes isolated as well, separated from the central fossette and forming an independent mediolabial fossette (Fig. 3.3) or internal fossette in Archaeohyrax suniensis (Billet et al., 2009). However, in Archaeopithecus, the isolation of this fossette seems to be independent from the increase of wear. There are much-worn specimens preserving the labial projection united to the central fossette (Figs. 2.15, 4.5, 4.6) and little-worn specimens showing the mediolabial fossette completely separated from the central part (Fig. 4.7, 4.9). As with the premolars, the distal cingulum in molars is much more developed than the mesial cingulum. M1-2 have hypocone more developed than protocone and lingually protruding (Fig. 4.8, 4.12), a feature also described for the notopithecid Antepithecus (Vera and Cerdeño, 2014; Vera, 2016), but in contrast to notopithecids, the protoloph-protocone are inclined and curving posteriorly in Archaeopithecus; there are some exceptions, however, in which the protocone protrudes lingually more than the hypocone, giving a 'bilobed' shape (Fig. 4.10). In some specimens (Fig. 4.12), M1 has a small 'cuspule' at the base of the sulcus between paracone and metacone, such as occurs in Notopithecus (Vera, 2013b). Besides the 'complex' central fossette, molars have mesio- and distolabial fossettes, which are irregular in shape and similarly sized. The occlusal surface shows the typical 'face' described for other groups of notoungulate, with fossettes occupying the eyes, mouth, and nose of this virtual face. These fossettes disappear in much-worn specimens (Fig. 3.3; $\mathrm{SW}=3$ in Fig. 5.1). The ectoloph is not as undulate as on premolars.

The M3 is characterized by its trapezoid shape, with the distal face narrower than the mesial face, producing a distally inclined labial face (Fig. 4.13); it differs from notopithecids, oldfieldthomasiids and other Eocene notoungulates in having a developed hypocone. The protocone is wider and more developed than the hypocone (Fig. 4.11, 4.13), whereas the opposite condition is observed in M1-2; in some cases, the protocone is pointed (Fig. 2.13). The wider protocone causes the central valley to be displaced distally. The mesial cingulum is low and short (Fig. 2.14), little to moderately developed, although also it can be absent (Fig. 2.13). The distal cingulum is as well developed as in M1-2, but differs in being more convex distally. The general pattern of fossettes is similar to that on M1-2: two labial fossettes, and the central fossette formed by two transverse and vertical parts; occasionally small fossettes form when the mesial and distal cingula merge with the occlusal surface. In worn specimens (Fig. 2.12), M3 assumes a nearly square outline and several fossettes are formed: the mesiolabial and distolabial fossettes, the shallow fossette between the mesial cingulum and protoloph, and a deeper fossette between the distal cingulum and metaloph, just below the distolabial fossette. 
Lower dentition.-There are three isolated teeth in lot AMNH FM 28782 (Fig. 3.5), here identified as most anterior lower incisors and/or canine. Two of them are conical and single-rooted; they do not have any lingual or labial sulci, unlike in notopithecids. One tooth $(2.0 \times 1.6 \mathrm{~mm})$ is a bit more labiolingually flattened than the other $(1.9 \times 1.8 \mathrm{~mm})$ and has a beveled distal crest. The third tooth is smaller and has a very low crown in comparison with the other teeth; its tip is rounded; it has a slightly concave internal face, whereas the external is convex. According to the size of the preserved alveolus in the lower jaw AMNH FM 28782, i1 is the smallest of the series, and $\mathrm{c}$ is approximately equal in size to i3. Their position demonstrates that the implantation of incisors is non-procumbent, which differs from Notostylops.

The premolars are characterized by having the trigonid longer than the talonid and a well-developed protostylid fold distally extended (Fig. 3.6), as described for p3-4 in Transpithecus (Vera, 2012a), but contrasting with Notopithecus, Antepithecus, Notostylops, and oldfieldthomasiids. Molars, instead, have trigonid much shorter than premolars and a longer talonid; the trigonid is particularly narrow and labially convex, with a lingually inclined protolophid. Occasionally, a very low conulid behind protoconid, between trigonid and talonid, is present on molars.

The p1 was not identified in the sample. On p2 (Fig. 3.6), the trigonid is narrower than the talonid, with two crests forming a V; the protolophid is mesiolingually very inclined; and the metalophid ends in a distally directed metaconid. The mesiolingual cingulid is narrow and low. The talonid is triangular in shape. The distal cingulid is low and wide, limiting a deep pit.

The p3-4 are similar to each other, premolariform (Fig. 3.6; Table 2), differing from molars as the homologous teeth in upper series (see above). The metalophid is a much-curved crest, and the metaconid is, in consequence, distally displaced in a postmetacristid; thus, the latter approaches to the entolophid, forming a fossettid in the talonid when worn. This well-developed postmetacristid is shared by notopithecids, but not by oldfieldthomasiids, henricosborniids, and notostylopids. The cristid oblique touches the metalophid at the middle point of the labial face. The protostylid can be absent (Fig. 4.15); such variability was also observed in Transpithecus (Vera, 2012a). There is a welldeveloped and low mesial cingulid, which merges with the protolophid and forms a long linguodistally oriented crest. The p3 of AMNH FM 28801 (Fig. 4.16) has an unworn conulid (entostylid) in the talonid basin, in contact with the entolophid; with wear, this conulid merges with the entolophid, giving it the mesial expansion observed on p4 and the molars; with more advanced wear, this expansion reaches the metaconulid, isolating a circular fossettid (Fig. 4.14). Comparing to the wear stage of premolars of AMNH FM 28782 (Fig. 3.6; Table 2), p2 is less worn than $\mathrm{p} 3$, and the latter has less wear than $\mathrm{p} 4$, although the difference in wear is more evident between $\mathrm{p} 2-3$ than $\mathrm{p} 3-4$. Based on this observation, it is assumed that $\mathrm{p} 2$ is the last premolar to erupt, and the sequence of eruption can be established as p4, p3, and $\mathrm{p} 2$. The same pattern was described for notopithecids, the henricosborniid Henricosbornia, some interatheriines (Vera and Cerdeño, 2014; Vera, 2016), and the hegetotheriid Paedotherium (Cerdeño et al., 2017).
The $\mathrm{m} 1$ and $\mathrm{m} 2$ are similar to each other, and it is difficult to differentiate them when they are isolated because it occurs with upper molars. A short-lived hypolophid is present (Fig. 4.16) and a tiny lingual cingulid connects hypolophid with entolophid, isolating a distal fossettid on the talonid (Fig. 4.17; SW = 1 and 2 in Fig. 5.3). In older individuals, however, the hypolophid and fossettids 'disappear' due to the merging of hypolophid and entolophid, and the talonid becomes subcircular (Fig. 4.15; SW = 3 in Fig. 5.3). The fossettid located between entolophid and hypolophid is more ephemeral than the central fossettid placed between metalophid and entolophid (Figs. 3.6, 4.14, 5.3). Molars have a well-developed entostylid, which is shared only with Pleurostylodon. The entostylid is highly variable in shape according to wear stage, being either hookshaped (Fig. 4.18) or bilobed (Fig. 4.19).

The $\mathrm{m} 3$ differs from $\mathrm{m} 1-2$ in the talonid. It is longer, has a long and well-developed hypolophid and a labial sulcus (hypoflexid), which is deeper than in other Eocene notoungulates (except Henricosbornia). Although absent in some individuals, there is a low lingual cingulid uniting entoconid and hypolophid and forming a distal fossettid, which is more evident when worn; differing from $\mathrm{ml}-2$, it is a deeper and long-term fossettid (Fig. 4.20). As in m1-2, the entostylid touches the metaconid and forms a mesial fossettid on the talonid; however, this entostylid is wider and can have small extra crests (Fig. 4.22). In some specimens (Fig. 4.21, 4.23), there is a small and low lingual cingulid that closes the valley between trigonid and talonid. In younger individuals (Fig. 4.24), trigonid and talonid are occlusally separated, but with wear the cristid oblique touches the metalophid at mid point. Molars have a short paralophid that merges in early stages of wear with the mesial cingulid, forming a long crest (Figs. 4.15, 4.16, 4.18, 5.3).

Postcranium.-Specimen AMNH FM 28895 includes the right Mc II and Mc III in anatomical connection (Fig. 6.1-6.3), an isolated metapodial (Fig. 6.4-6.7), a fragment of phalange, and a fragment of left ulna (Fig. 6.8, 6.9). The metacarpals are poorly preserved. Mc II is distally incomplete, but it would be shorter than Mc III (Fig. 6.1; Table 4); the proximal articular surface of Mc II is deeper and wider than that of Mc III (Fig. 6.2); the proximointernal face is broken.

Mc III has a laterally compressed proximal half (AP $>$ T), an anteroposteriorly flattened distal half $(\mathrm{AP}<\mathrm{T})$, and is approximately square at the midpoint (Fig. 6.1; Table 4); there is a concave proximoexternal facet for Mc IV, formed by two lunate sections, with the anterior being larger than the posterior part (Fig. 6.3); the proximal articular surface is asymmetrically triangular. The length of Mc III is comparable to the dimensions of the Mc III of Colbertia magellanica (Bergqvist and Fortes Bastos, 2009). Dimensions of Mc II-III (Table 4) are larger than those reported by Vera (2012b, table 4) for the metapodials of Notopithecus adapinus.

The isolated metapodial AMNH FM 28895 is significantly shorter than Mc II-III (Table 4). This difference in size occurs, for example, among metacarpals of the Interatheriinae Protypotherium, Miocochilius, and Federicoanaya, in which Mc V has almost half the length of Mc III (Sinclair, 1909; Stirton, 1953; Hitz et al., 2008). Based on this comparison (Eocene associated metapodials are practically unknown) and by association with the other metacarpals present in the lot 


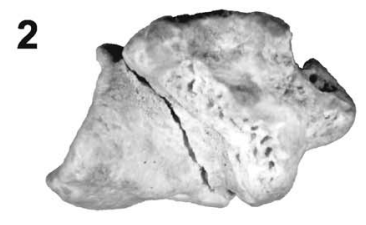

1

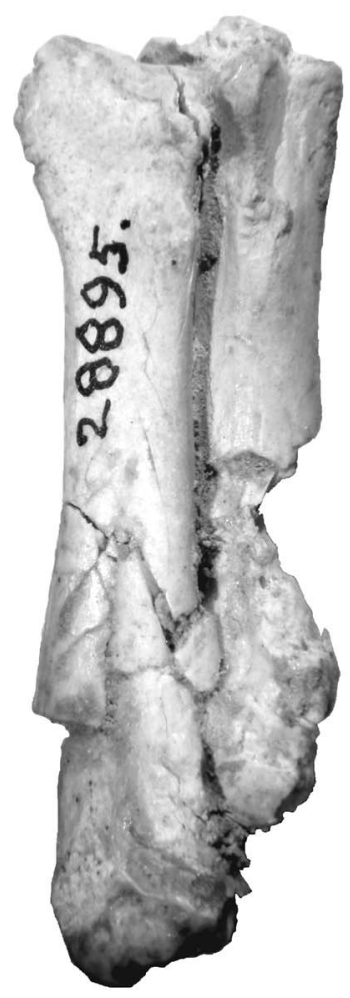

3

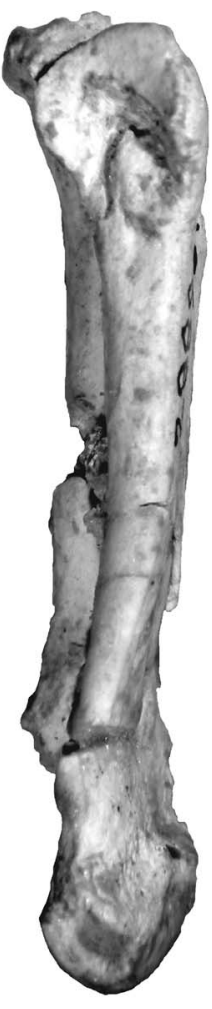

4

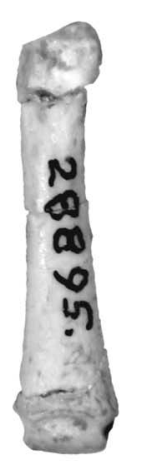

5

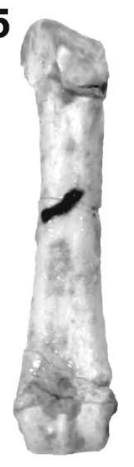

6

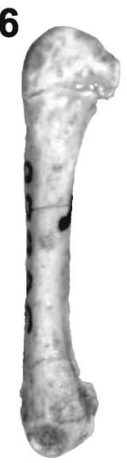

7

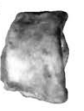

8

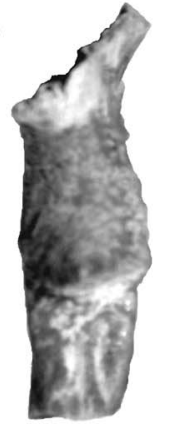

9

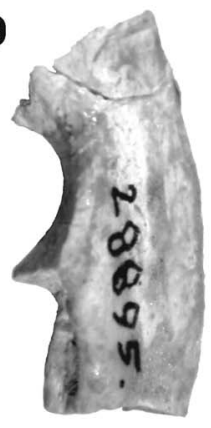

Table 4. Measurements $(\mathrm{mm})$ of the metapodials of AMNH FM 28895. $\mathrm{APD}=$ anteroposterior diameter; diap $=$ diaphysis; dist $=$ distal; $\mathrm{L}=$ length; $\mathrm{px}=$ proximal; $\mathrm{W}=$ width. Dashes represent not measured dimensions.

\begin{tabular}{lccr}
\hline & Mc III & Mc II & Mc V \\
\hline L & 34.5 & - & 15.9 \\
W px & 6.5 & 6.1 & 2.6 \\
W dist & 7.0 & - & 3.9 \\
APD px & 6.3 & 8.2 & 3.7 \\
APD dist & 4.5 & - & 2.7 \\
W diap & 6.5 & - & 2.4 \\
APD diap & - & - & 1.7 \\
\hline
\end{tabular}

AMNH FM 28895, the isolated bone is here tentatively considered a right $\mathrm{Mc} \mathrm{V}$ (Fig. 6.4-6.7). It is complete, but fractured; the body is nearly straight and quadrangular in section (Fig. 6.4, $6.5)$; the proximal epiphysis is laterally compressed and the distal epiphysis is anteroposteriorly flattened (Fig. 6.6). The proximal facet is rectangular in shape, anteroposteriorly very convex, and laterally inclined (Fig. 6.7); posteriorly, the surface extends downwards in a small fan-shaped area (Fig. 6.5). Internally, just below the surface, there is a thin ridge that borders a concavity. The external face is convex and has no distinctive facet. The distal articular surface is anteriorly convex and has a moderately developed keel on the posterior face (Fig. 6.7); in anterior view, a semi-circular sulcus separates the articulation from the shaft.

The ulna fragment (Fig. 6.8, 6.9) has a moderately concave and nearly vertically oriented articular facet for the humerus, similar to the ulna of Notopithecus adapinus (Vera, 2012b) and differing from the curved surface observed in Protypotherium (YPM-PU 0-15828, YPM-PU 0-15341; also see Sinclair, 1909).

\section{Discussion}

Variation throughout ontogeny and systematic implications.It is widely known that wear modifies the dimensions and morphology of the dentition of herbivorous mammals throughout ontogeny. In particular, among native ungulates from South America, ontogenetic sequences based on extreme morphological changes on dentition were described for Archaeohyracidae (Croft et al., 2003; Billet et al., 2009; Cerdeño et al., 2010), the notopithecid Transpithecus (Vera, 2012a), and other groups of notoungulates (Francis, 1960; Madden, 1997; Billet et al., 2008; Cerdeño et al., 2008).

Concerning archaeopithecids, the morphological changes on the occlusal surface of upper and lower dentition became really noticeable as wear progresses. However, these changes were originally assumed to represent taxonomic differences, therefore Ameghino $(1897,1901,1902,1903)$ erected at least six species of archaeopithecids. Simpson (1967b) regarded the same criteria, but he reduced the number of species and recognized variation. On this aspect, Croft et al. (2003) provided the basis for interpreting wear-related metric variation in archaeohyracids tooth dimensions and demonstrated that most cheek teeth decrease in length and increase in width through

Figure 6. Archaeopithecus rogeri. AMNH FM 28895: (1-3) right Mc II-III, (1) anterior, (2) proximal (anterior face to bottom) and (3) lateral views; (4-7) right $\mathrm{Mc} \mathrm{V},(\mathbf{4})$ anterior, (5) posterior, (6) internal, (7) proximal and distal views; $(\mathbf{8}, \mathbf{9})$, fragment of left ulna, (8) anterior and (9) lateral views. Scale bar is $5 \mathrm{~mm}$. 
increasing wear, which should be taken into account when interpreting the systematic significance of metric differences among specimens of different wear states.

The present revision of archaeopithecid teeth highlights, for example, that in barely worn teeth (e.g., 1 in Fig. 7) the mesial cingulum is low (nearly at the base of the crown), the protocone and the hypocone are separated (the entolophe is not formed or incipient), and the central fossette preserves its vertical part (Figs. 2.4, 2.5, 4.11; $\mathrm{SW}=1$ in Fig. 5.1); in contrast, in much more worn teeth (e.g., 3 in Fig. 7), the cingulum merges with the occlusal surface until disappearing, and the protocone and hypocone are occlusally joined by the entoloph at the same level (Figs. 2.15, 3.3, 4.12; SW $=2$ in Fig. 5.1). The same occurs with fossettes and sulci: they are present in younger individuals and disappear or are attenuated in older individuals. All these alterations throughout ontogeny modify the occlusal surface appearance. Nevertheless, the most striking changes with wear concern tooth metric variations. Unworn upper molars (M1-2) are nearly square (MDD $\approx$ LLD), but with wear, the width increases much more than the length (MDD < LLD), and consequently become rectangular (see open triangles 1-3, Figure 7). In turn, P4 changes in both dimensions with wear: the younger specimens are narrower and shorter (e.g., 1 in Fig. 7) than those with moderate wear (e.g., 2 in Fig. 7), while the older teeth are the longest and widest (e.g., 3 in Fig. 7). With respect to lower dentition, the tendency is not as clear as for the upper homologous teeth due to an overlapping among wear categories; in general, however, $\mathrm{m} 1$ and $\mathrm{m} 2$ tend to widen and shorten with increasing wear, although this is not as evident as in archaeohyracids (Croft et al., 2003). These authors suggested that the coefficient of variation (CV) has important implications to distinguish species using metric values alone in the absence of other corroborating morphological distinctions. In the Archaeopithecidae sample, the coefficient of variation assumes values below $11 \%$ for all cheek teeth, disregarding wear (Table 1), and below $13 \%$ considering wear separately (see Supplemental Data); this translates as low variation on teeth dimensions. The higher variation $(\mathrm{CV}<13 \%)$, which considers wear categories, emphasizes the difficulty to classify individual teeth to a particular stage of wear.

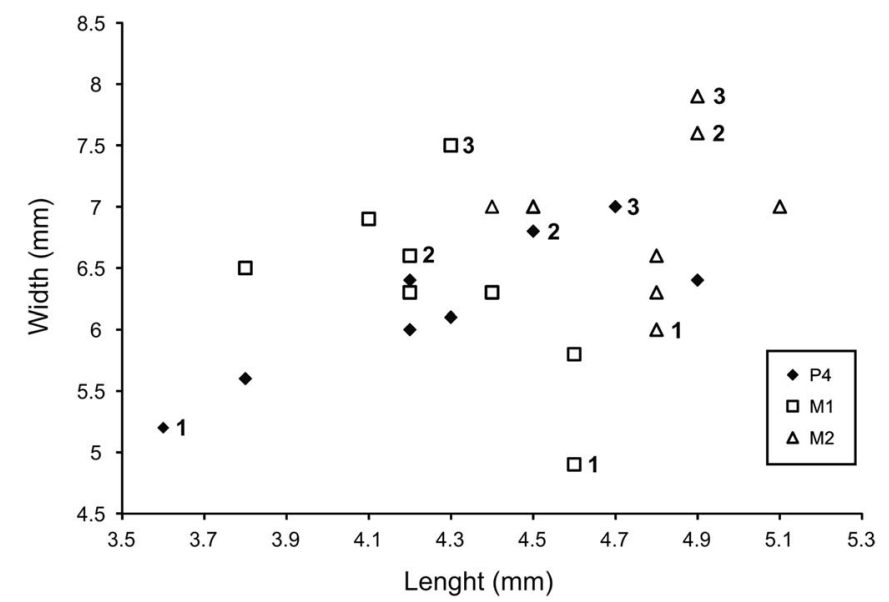

Figure 7. Bivariate plot of eight specimens preserving $\mathrm{P} 4-\mathrm{M} 2$ row-teeth in different stages of wear (SW). (1) MACN-A 10813c, SW = 1; (2) MMdP-M $727, \mathrm{SW}=2 ;(3) \mathrm{AMNH} F M 28782, \mathrm{SW}=3$.
In addition, despite the fact that the dentition of Archaeopithecus is brachydont and develops roots, height varies markedly through increasing wear (Fig. 5. 2, 5.4), from relatively high-crowned teeth ( $\mathrm{SW}=1 \mathrm{in}$ Fig. $5.2,5.4$ ) to very low-crowned teeth ( $\mathrm{SW}=3$ in Fig. 5.2, 5.4). With respect to this peculiarity, Simpson (1967b, p. 62) observed how the age of an individual influenced tooth dimensions and argued that the accelerated hypsodonty revealed by archaeopithecids might hint at a possible relationship with archaeohyracids. On this aspect, however, it is important to distinguish that archaeopithecids have brachydont-rooted dentition, which is relatively higher crowned than in other typical short-crowned Eocene notoungulates, whereas archaeohyracids are characterized by rootless, ever-growing teeth (hypselodont dentition; Simpson, 1970).

Regardless of the ontogenetic stage of the individual, the presence of mesial cingulum on upper dentition is a variable feature in the archaeopithecid sample studied, and is here considered an intraspecific variation or a polymorphic character in phylogenetic terms. This variation was also mentioned by Simpson (1967b) for the teeth sample referred to Acropithecus rigidus (see above). This statement is crucial because the presence of a mesial cingulum was one of the characteristics alluded to by Tejedor et al. (2009) for assigning their material to Archaeopithecus rogeri.

The present revision, based on more than 200 catalogued specimens, including the type material of the species defined by Ameghino and several collections (e.g., AMNH, MGP, MNHN, MLP), does not support the differentiation of archaeopithecids into two genera and three species as proposed by Simpson (1967b) or two monospecific genera as suggested by Vera (2013b). On the contrary, the present work identifies only one morphological pattern showing morphological transformations throughout ontogeny, from unworn to much more worn teeth, and presenting some polymorphic characters that reflect intraspecific variation. This documented difference in shape of the occlusal surface is associated with wear-related metric variation in teeth dimensions. Thus, a previous taxonomic overestimation is evident, and only one monotypic genus, Archaeopithecus rogeri, is validated.

It should be noted that the Scarritt Pocket collection at AMNH also includes uncatalogued isolated teeth ( 200 pieces), which have field numbers and were previously identified as archaeopithecids by Simpson (1967b, p. 63-65), who collected them in Patagonia. As part of the present revision, all these teeth were studied during two visits to the AMNH and compared with the type specimens of the Ameghino collection, which allowed me to recognize on them the morphometric characteristics described for Archaeopithecus rogeri.

Concerning nomenclature, Archaeopithecus rogeri is the type species and the first one described by Ameghino (1897) in Archaeopithecidae; in addition, the type specimen is a nearly complete maxilla ( $\mathrm{P} 1-\mathrm{M} 2)$, enough to represent the morphological characteristics of the taxon. Further, the name Archaeopithecus Ameghino, 1897 has nomenclatural priority over Acropithecus Ameghino, 1901, according to the ICZN (2000). Based on the above-mentioned explanations, Archaeopithecus rogeri is here considered as the valid name for the single recognized species. Under this proposition, the name Acropithecus rigidus, resulting from transferring Archaeopithecus rigidus to Acropithecus (Simpson, 1967b), is consequently discarded. 
Phylogenetic analysis.-Exhaustive revision of many specimens of Archaeopithecus rogeri has permitted improved codification of some characters with respect to Vera's (2016) matrix. Sixty-nine of 87 characters were scored for Archaeopithecus rogeri (Supplemental Data 1). For example, the eruption sequence of permanent premolars follows a postero-anterior direction as in notopithecids $\left(4^{1}\right), \mathrm{P} / \mathrm{p} 1$ are not overlapped by $\mathrm{P} / \mathrm{p} 2$ or $\mathrm{C} / \mathrm{c}\left(12^{2}\right.$ and $\left.37^{\circ}\right), \mathrm{i} 3$ is larger than $\mathrm{i} 2\left(31^{\circ}\right)$, $\mathrm{c}$ is larger than incisors $\left(35^{1}\right)$, and the paralophid is reduced on molars $\left(51^{1}\right)$. Other characters, such as those related to the mesial cingulum on P3-4 and M1-2 (characters 18 and 19), the development of hypocone versus protocone on M1-2 (character
22), and the lingual sulcus on P3-4 (characters 25 and 26), were coded as polymorphic (Supplemental Data 1).

The phylogenetic analysis yielded 204 most-parsimonious trees, 289 steps long, with a consistency index (CI) of 0.38 , and a retention index (RI) of 0.69. In the strict consensus (Fig. 8.1), two basal polytomies are recovered; node A gathers Colbertia and Notostylops as the most basal genus of node B. This latter includes Archaeopithecus rogeri and other Eocene notoungulates, such as Kibenikhoria, Henricosbornia, Oldfieldthomasia, Pleurostylodon, and two clades: notopitheciids and node $\mathrm{C}$ (grouping interatheriids, hegetotheres, mesotheres, and archaeohyracids). Nodes B and D (Fig. 8.1) are well supported
1

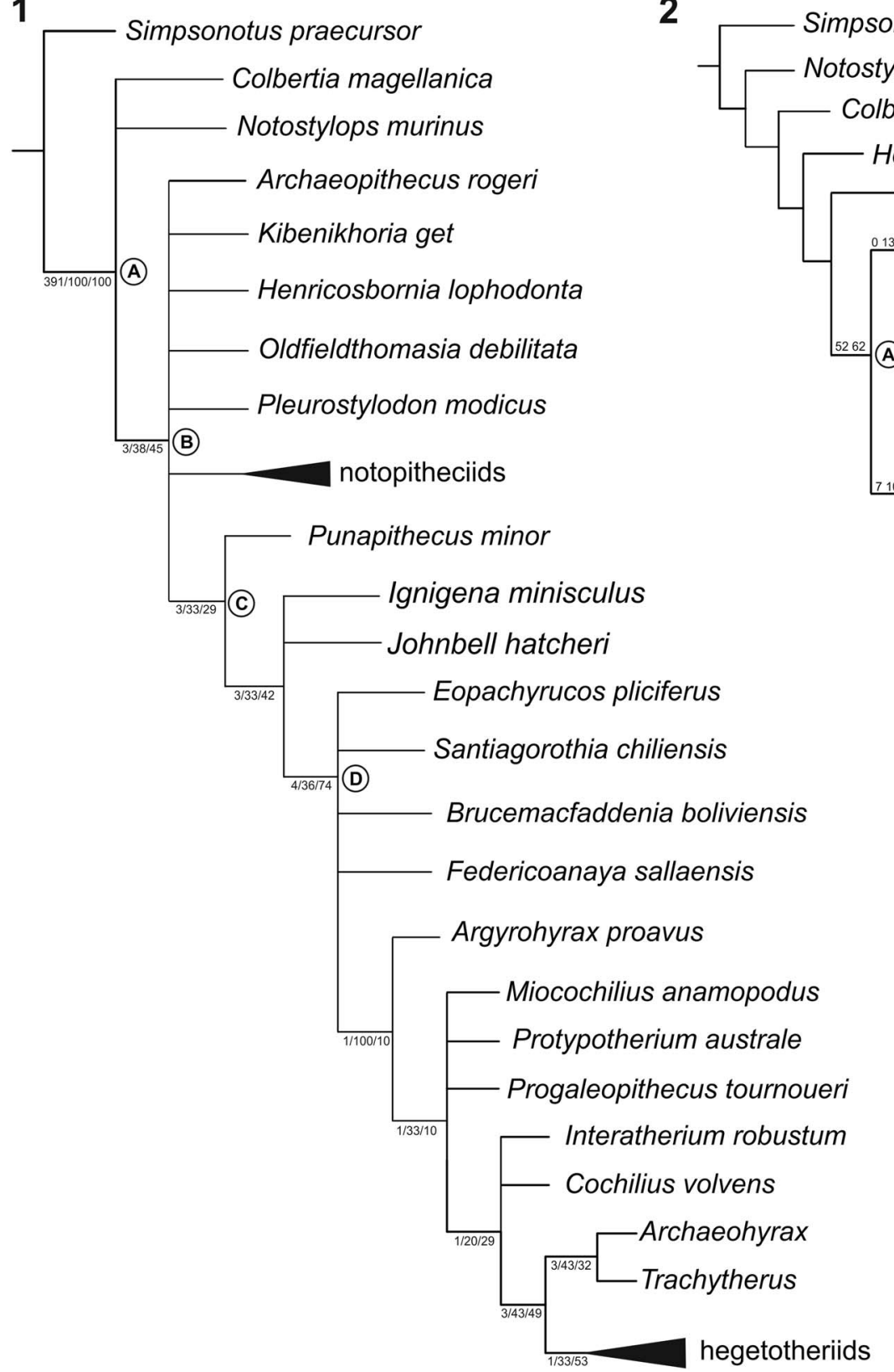

Figure 8. (1) Strict consensus from the 204 most parsimonious trees ( 289 steps, $\mathrm{CI}=0.38, \mathrm{RI}=0.69$ ) obtained under equally weighted characters. (2) Tree 0/204, showing a particular arrange for Acropithecus rogeri in relation to other Eocene notoungulates. Synapomorphies are shown above branches. Numbers below branches, from left to right, correspond to absolute BS, relative BS and Symmetric Resampling values. Letters A-F refer to nodes, which are explained in text; (*) indicates synapomorphies $1,13,17,25,26,61,64,65,68,69,80$. 
by, respectively, 11 synapomorphies $(5,7,10,12,28,29,33$, $35,42,52$, and 66) and 12 synapomorphies $(3,13,17,20,25$, 26, 27, 34, 36, 40, 49, and 66).

It should be highlighted that Archaeopithecus rogeri is not grouped into the notopithecid clade, being the most noteworthy difference with respect to Vera's (2016, fig. 2B) cladogram, where A. rogeri is the sister taxon of the clade gathering Transpithecus and Guilielmoscottia. In fact, in one of the most parsimonious topologies (tree 0 of 204; Fig. 8.2), Archaeopithecus rogeri (with 10 autapomorphies) splits from node A as sister taxon of a mostinclusive clade (node B), gathering the notopithecid clade (node C) and node D, which groups some oldfieldthomasids (node E) and node F (interatheriids, hegetotheres, mesotheres, and archaeohyracids). Node A (Fig. 8.2) links Archaeopithecus rogeri with node B by two synapomorphies: 52 and 62 . According to this result, Archaeopithecus rogeri is a basal notoungulate, not directly related to any group (family) of this order; therefore, previous hypotheses linking this taxon to Oldfieldthomasia (Reguero and Prevosti, 2010) or notopithecids (Vera, 2016) are discarded.

The strict consensus (Fig. 8.1) yielded relatively good branch support and a good fit with the stratigraphic record of the taxa included, in agreement with the topology obtained by Vera (2016, fig. 2B). However, the relationships among Eocene taxa are not well established, as shown the polytomies on nodes A and B (Fig. 8.1 ), in comparison with the better resolution of more-derived notoungulate groups. These particular polytomies are due to the shifting position mainly of the oldfieldthomasiids members, such as Kibenikhoria and Oldfieldthomasia (Fig. 8.2; node E).

Despite recognizing only one taxon, the family Archaeopithecidae as a Linnaean hierarchical rank is here maintained until new studies of basal groups are undertaken, and the relationships among Paleogene notoungulate families are identified more clearly.

Body mass estimation and paleoecological inferences.-Size, which is one attribute of niche differentiation in herbivorous mammals (Jarman, 1974; Owen-Smith, 1988), also allows understanding the paleobiology and paleoecology of a fossil organism (Elissamburu, 2012). The most common way to estimate body mass in fossil ungulates is applying allometric equations derived from extant mammals, using linear regression based on dental, craniomandibular, and postcranial measurements (Damuth, 1990; Janis, 1990; Scott, 1990; Mendoza et al., 2006; Tsubamoto, 2014). Particularly for ungulates, Janis (1990) realized that the parameters with less variation and greater correlation with body mass on herbivorous ungulates were the lengths (MDD) of each lower molar (m1, m2, and m3), M2, and the series m1-3, with the last being the most reliable. Several estimations were carried out for different groups of South American notoungulates (Madden, 1997; Elissamburu, 2004; Elissamburu and Vizcaíno, 2004; Croft and Anderson, 2008; Reguero et al., 2010; Vizcaíno et al., 2010; Scarano et al., 2011; Cassini et al., 2012a; Elissamburu, 2012), including a geometric morphometric approach by Cassini et al. (2012b). Based on several allometric equations from different authors, Elissamburu (2012) estimated body size for 50 genera of Notoungulata and proved that lower molar row length (LMRL) and first lower molar length (FLML) offer more stable estimation values, with Janis' (1990) predictors being best for notoungulate taxa with unknown postcranial bones, such as most of the Eocene groups. Specifically, regarding early
Paleogene Patagonian taxa, Elissamburu (2012; table 2) provided mean body mass values for archaeopithecids (Acropithecus) and notopithecids (Notopithecus). In turn, Scarano et al. (2011) proposed new linear regression models that proved to be most successful for small herbivorous ungulates with body mass under $13 \mathrm{~kg}$; for larger ungulates, the equations postulated by other authors (Damuth, 1990; Janis, 1990) worked better.

Following these inferences, body mass was estimated for Archaeopithecus rogeri and notopithecids (Notopithecus, Antepithecus, Transpithecus, and Guilielmoscottia) using Vera's (2013b) dataset and applying equations from Janis (1990) and Scarano et al. (2011). In particular for Notopithecus, body mass was also inferred from astragalar parameters (Tsubamoto, 2014) based on one specimen (MPEF-PV 1113, Vera, 2012b). Mean values for each model and taxon, as well as the average total, are listed in Table 3.

Taking into account average total values (Table 3), the estimated body mass of Archaeopithecus rogeri $(1.62 \mathrm{~kg}$ ) falls between the estimated values for the notopithecids Notopithecus adapinus $(1.40 \mathrm{~kg})$ and Antepithecus brachystephanus Ameghino, $1901(1.68 \mathrm{~kg})$, and is surpassed by Transpithecus obtentus (1.82 kg) and Guiliemoscottia plicifera $(2.38 \mathrm{~kg})$. However, after exploring each model separately and applying second lower molar length (SLML), third lower molar length (TLML), and m1-3 length (LMRL) models, the body mass of the archaeopithecid is higher than that of $N$. adapinus and A. brachystephanus, but is still surpassed by the predicted mass values for T. obtentus and G. plicifera (Table 3). In summary, the body mass values obtained for Archaeopithecus rogeri fall within the range between $1.43 \mathrm{~kg}$ and $2.57 \mathrm{~kg}$, overlapping the values for notopithecids (Table 3) and the hegetotheriids Pachyrukhos and Paedotherium ( 2 kg, Cassini et al., 2012a, 2012b; Elissamburu, 2012), but below the body mass estimated for the interatheriinae Protypotherium australe $(\sim 8 \mathrm{~kg}$, Scarano et al., 2011; Cassini et al., 2012a; 3-5 kg, Cassini et al., 2012b; $\sim 7 \mathrm{~kg}$, Elissamburu, 2012). Indeed, the body mass estimates of the present study for Notopithecus and Archaeopithecus (Table 3) are very close to those previously reported by Elissamburu (2012, table 2). In contrast, when considering models based on postcranial remains, body mass values are higher than those based on dental models, as it is corroborated for Notopithecus (Table 3; Elissamburu, 2012); in this case, when applying Tsubamoto (2014) models based on astragalar lineal measurements, body masses predicted for Notopithecus do not vary between equations (Table 3 ), and their values are closer to those estimated using humerus length than those based on other long bones (Elissamburu, 2012).

Archaeopithecus rogeri is a brachydont notoungulate restricted to the Casamayoran SALMA, but characterized by having relatively higher crowns than other contemporaneous brachydont groups, such as notopithecids and oldfieldthomasiids. Explaining this incipient protohypsodonty (Mones, 1982) is not easy, given that Archaeopithecus is ancestral to any other notoungulate group; phylogenetic effects and an adaptive differential use of feeding source (substrate preference) should be considered, particularly during the middle Eocene when a global cooling occurred and open-vegetation habitats expanded in central Patagonia (Bellosi and Krause, 2014, and references therein). 
Biostratigraphic context.-Within Ameghino's published work, all of his Archaeopithecidae members (excepting Guilielmoscottia, which was later transferred to notopithecids, see above), were described for the Casamayoran levels (Eocene) of the Sarmiento Formation (Patagonia). Ameghino usually differentiated specimens based on their origin, either from the 'low' or 'upper' sections of the Casamayoran, but unfortunately many of his specimens presently lack this important stratigraphic information. Cifelli (1985) recognized two distinguishable sections in the traditional Casamayoran age, which later were referred to the Vacan and Barrancan subages. At present, the Vacan (the lower section or Cañadón Vaca Member, 43.1-46.9 Myr; Bellosi and Krause, 2014) and the Barrancan (the upper section or Gran Barranca Member, 42-39 Myr; Bellosi and Krause, 2014) are considered to be LutetianBartonian, respectively (Woodburne et al., 2014a, 2014b, and references therein). In turn, all the specimens referred by Simpson (1967b) to Acropithecus rigidus come from the Casamayoran lower levels of Cañadón Vaca, which is the type locality of the Vacan subage (Cifelli, 1985). This locality is very near to 'Oeste de Río Chico,' which produced some of the Ameghino type specimens (Simpson, 1967a; Fig. 1). According to Simpson (1967a, p. 65), the assemblage from Cañadón Vaca is more similar to Ameghinos' specimens from 'Oeste de Río Chico' than those from Colhué Huapi. In addition, many other specimens recognized here as Archaeopithecus rogeri derive from localities at Barrancan levels, such as Colhué Huapi (where the Cañadón Vaca section is absent; Bellosi and Krause, 2014), and are contemporaneous with the notopithecid remains. The specimens in the Egidio Feruglio collection, curated at the MGP, have information about locality, but the stratigraphic origin is not precise.

Simpson (1935a, 1935b) referred to a Notopithecidae indet. and ?Transpithecus sp. from Cañadón Hondo; however, Vera (2012a) determined that the specimen mentioned by Simpson (1935a) does not correspond to Transpithecus or any member of the notopithecid group (or any other specimen from the Cañadón Hondo fauna in the AMNH collection), and referred it instead to the archaeopithecid morphotype (AMNH FM 28534). This is the only fossil from Cañadon Hondo recognized as an archaeopithecid after several years of research and two visits to the AMNH. Particularly for the Cañadón Hondo area, Raigemborn et al. (2010) postulated that the Gran Barranca Member of the Sarmiento Formation is equivalent to the Cañadón Hondo Formation (Andreis, 1977) and that it overlies the Las Flores Formation. In turn, Bellosi and Krause (2014) proposed a correlation between the Cañadón Vaca Member (of the Sarmiento Formation) and the lower and middle sections of the Cañadón Hondo Formation, as well as between the Gran Barranca Member and the upper section of Cañadón Hondo Formation. This means that Simpson's fossil from Cañadón Hondo (AMNH FM 28534) could have come from levels younger than Itaboraian age. The same situations could apply to the specimens coming from the Bajo Palangana, and Cerro Blanco localities, where there are levels of both the lower section of the Sarmiento Formation (Gran Barranca Member) and the Río Chico Group (Riochican SALMA, late Paleocene-middle Eocene; Raigemborn et al., 2010, and references therein), but the stratigraphic origin of these specimens is unclear.
Concerning new records of archaeopithecids (Cladera et al., 2004; Tejedor et al., 2009; Gelfo et al., 2010; and Bauzá et al., 2016), it is necessary to clarify some points. In the case of Acropithecus remains from the Las Violetas fauna, these were recovered from outcrops, uncomformably overlying the Las Violetas Formation (Gelfo et al., 2010), assigned to Las Flores Formation (Río Chico Group), and referred to early Eocene (Bauzá et al., 2016). In turn, the presence of Archaeopithecus in the fauna from Paso del Sapo (Tejedor et al., 2009) is not discarded, bearing in mind that the Paso del Sapo fauna fills the gap between the Riochican SALMA and Vacan subage (Woodbourne et al., 2014b; but see Krause et al., 2017); however, the taxonomic affinities of these remains need to be corroborated. Finally, if the record of Archaeopithecus in the Mustersan levels of Gran Hondonada (Cladera et al., 2004) is confirmed, it would imply the youngest record and the biochronological extension of this taxon.

In sum, although Archaeopithecus rogeri is present in the Cañadón Vaca and Gran Barranca members, it is more common in the Vacan than the Barrancan subage. The first (Riochican SALMA) and last (Mustersan SALMA) appearances proposed for Archaeopithecus still need to be confirmed (see discussion above).

\section{Conclusions}

This systematic revision of hundreds of specimens referred to archaeopithecids has permitted identifying only one morphotype, which shows ontogenetic variation in both size and morphology, and intraspecific variability for some characters. Consequently, only one taxon is recognized among the many species originally described for the group.

Nomenclatorial priority supports Archaeopithecus rogeri as a valid name. In this sense, the names of all species described by Ameghino into Archaeopithecidae (Archaeopithecus alternans, A. rigidus, Acropithecus tarsus, and Ac. plenus) become synonymous with Archaeopitecus rogeri, including the combination Acropithecus rigidus proposed by Simpson (1967b). Regarding the lectotype (MACN-A 10824a) of Notopithecus fossulatus, this specimen is here recognized as an archaeopithecid; thus, the name $N$. fossulatus (and Archaeopithecus fossulatus sensu Simpson, 1967b) is considered synonymous with Archaeopithecus rogeri.

In contrast to the other Casamayoran brachydont taxa, such as notopithecids and oldfieldthomasiids, Archaeopithecus displays incipient higher-crowned dentition, conical upper/lower incisors and canines, short diastemata between anterior teeth, a parastyle on $\mathrm{P} 1$, non-overlapping $\mathrm{P} / \mathrm{p} 1$, hypocone developed on M3, non-procumbent lower incisors, a well-developed protostylid fold on p2-4, a reduced paralophid and well-developed entostylid on lower molars, and a deep hypoflexid on talonid of $\mathrm{m} 3$. Archaeopithecus shares the eruption sequence of permanent premolars and the well-developed entostylid on lower molars with notopithecids and Pleurostylodon, respectively. Some characters are polymorphic, such as presence/absence of the mesial cingulum and lingual sulcus on upper teeth. Additionally, Archaeopithecus teeth show variable occlusal morphology throughout ontogeny, which is associated with a wear-related variation in dental dimensions. With increasing wear, upper 
molars became wider, while lower molars tended to widen and shorten.

Based on the phylogenetic analysis, Archaeopithecus rogeri is not recovered as a member of the notopithecid clade or together with Oldfieldthomasia, contrary to previous hypotheses (Reguero and Prevosti, 2010; Vera, 2016). In fact, Archaeopithecus rogeri occurs in basal position in relation to Typotheria, forming a polytomy with other Eocene taxa, such as the isotemnid Pleurostylodon modicus, Henricosbornia, and some oldfielthomasiids.

The body masses for Archaeopithecus rogeri and the notopithecids were estimated using different regression models based on dental measures, and on postcranial parameters in the case of Notopithecus. The mean value calculated for Archaeopithecus rogeri $(1.62 \mathrm{~kg})$ is very close to those for Notopithecus adapinus $(1.40 \mathrm{~kg})$ and Antepithecus brachystephanus $(1.68 \mathrm{~kg})$, and slightly lower than Transpithecus obtentus $(1.82 \mathrm{~kg})$ and Guiliemoscottia plicifera $(2.38 \mathrm{~kg})$, all of which have body sizes comparable to those of the hegetotheriids Pachyrukhos and Paedotherium.

Archaeopithecus rogeri currently has been reported only from Eocene localities of Chubut Province (Argentina). Its biostratigraphic range is from Vacan (early middle Eocene) through Barrancan (late middle Eocene) subages. Older records from the Riochican SALMA need to be stratigraphically confirmed. In addition, purported archaeopithecids from the Paso del Sapo fauna, Gran Hondonada (Mustersan SALMA), and Las Violetas localities, lack published descriptions to verify their taxonomic designation. Therefore, the lower and upper limits of the archaeopithecid biochron are still tentative.

\section{Acknowledgements}

Thanks are due to the editors of the Journal, D. Croft, and an anonymous reviewer for their constructive suggestions that improved the manuscript. I am also grateful to the following institutions and people who provided access to the collections under their care: J. Meng, J. Galkin, and A. Gishlick (AMNH); A. Kramarz and S. Álvarez (MACN); M. Fornasiero and L. del Favero (MGP); M. Reguero and M. Bond (MLP); C. Argot (MNHN); F. Scaglia and A. Dondas (MMdP); E. Ruigómez (MPEF); and D. García López and J. Powell (PVL). I am indebted to C. Bottero, who revised the English language, P. Meglioli (IANIGLA), who helped with statistical analysis, R. Bottero (IANIGLA), who prepared Figure 1, and F. Magliano for technical assistance. The Campo Muriette location (Fig. 1) was kindly provided by M. Krause and P. Puerta (MPEF). This research was financially supported by: "Consejo Nacional de Investigaciones Científicas y Técnicas" (CONICET, Argentina), postdoctoral scholarship for short stays abroad (Resolution D N 4778); the scholarship committee of the Field Museum of Natural History, USA (grant 2010-P305326); a Williams Foundation travel grant (2011); and two "Proposte di finanziamento per azioni di cooperazione universitaria” grants (2011 and 2014) by the University of Padova, Italy.

\section{Accessibility of supplemental data}

Data available from the Dryad Digital Repository: http://doi. org/10.5061/dryad.h2900

\section{References}

Ameghino, F., 1897, Les mammifères crétacés de l'Argentine. Deuxième contribution à la connaissance de la faune mammalogique des couches à Pyrotherium: Boletín del Instituto Geográfico Argentino, v. 18, p. 1-117.

Ameghino, F., 1901, Notices préliminaires sur les ongulés nouveaux des terrains crétacés de Patagonie: Boletín de la Academia Nacional de Ciencias de Córdoba, v. 16, p. 348-426.

Ameghino, F., 1902, Notices préliminaires sur les mammifères nouveaux des terrains crétacés de Patagonie: Boletín de la Academia Nacional de Ciencias de Córdoba, v. 17, p. 5-70.

Ameghino, F., 1903, Nuevas especies de mamíferos cretáceos y terciarios de la República Argentina: Anales de la Sociedad Científica Argentina, v. 56, p. 193-208.

Ameghino, F., 1904, Recherches de morphologie phylogénétique sur les molaires supérieures des ongulés: Anales del Museo Nacional de Buenos Aires, v. 3, no. 3, p. 1-541.

Ameghino, F., 1906, Les formations sédimentaires du Crétacé supérieur et du Tertiaire de Patagonie: Anales del Museo Nacional de Buenos Aires, v. 15, p. $1-568$.

Andreis, R.R., 1977, Geología del área de Cañadón Hondo, Departamento Escalante, provincia del Chubut, República Argentina: Museo de La Plata, Obra del Centenario, v. 4, p. 77-102.

Bauzá, N., López, G.M., and Gelfo, J.N., 2016, Los Notoungulata (Mammalia: Pan-Perissodactyla) del Eoceno temprano de la localidad de Las Violetas, Patagonia Argentina: XXX Jornadas Argentinas de Paleontología de Vertebrados: Buenos Aires, Resúmenes, p. 13.

Bellosi, E.S., and Krause, J.M., 2014, Onset of the Middle Eocene global cooling and expansión of open-vegetation habitats in central Patagonia: Andean Geology, v. 41, p. 29-48.

Bergqvist, L., and Fortes Bastos, A.C., 2009, A postura locomotora de Colbertia magellanica (Mammalia, Notoungulata) da bacia de São José de Itaboraí (Paleoceno Superior), Río de Janeiro, Revista Brasileira de Paleontologia, v. 12, p. $83-89$.

Billet, G., 2011, Phylogeny of the Notoungulata (Mammalia) based on cranial and dental characters: Journal of Systematic Palaeontology, v. 1, p. 1-17.

Billet, G., Muizon, C. de., and Mamaní, B., 2008, Late Oligocene mesotheriids (Mammalia, Notoungulata) from Salla and Lacayani (Bolivia): implications for basal mesotheriid phylogeny and distribution: Zoological Journal of the Linnean Society, v. 152, p. 153-200.

Billet, G., Patterson, B., and Muizon, C. de, 2009, Craniodental anatomy of late Oligocene archaeohyracids (Notoungulata, Mammalia) from Bolivia and Argentina and new phylogenetic hypotheses: Zoological Journal of the Linnean Society, v. 155 , p. 458-509.

Bremer, K., 1990, Combinable component consensus: Cladistics, v. 6, p. 369-372. Cassini, G.H, Cerdeño, E., Villafañe, A.L., and Muñoz, N.A., 2012a, Paleobiology of Santacrucian native ungulates (Meridiungulata: Astrapotheria, Litopterna, and Notoungulata), in Vizcaíno, S.F., Kay, R.F., and Bargo, M.S., eds., Early Miocene Paleobiology in Patagonia: High-Latitude Paleocommunities of the Santa Cruz Formation: Cambridge, Cambridge University Press, p. 243-286.

Cassini, G., Vizcaíno, S.F., and Bargo, S., 2012b, Body mass estimation in Early Miocene native South American ungulates: a predictive equation based on 3D landmarks: Journal of Zoology, v. 287, p. 53-64.

Cerdeño, E., Chiesa, J., and Ojeda, G., 2008, Presence of Oxyodontherium (Macraucheniidae, Litopterna) in the Río Quinto Formation, San Luis (Argentina): Journal of South American Earth Sciences, v. 25, p. 217-226.

Cerdeño, E., Reguero, M., and Vera, B., 2010, Deseadan Archaeohyracidae (Notoungulata) from Quebrada Fiera (Mendoza, Argentina) in the paleobiogeographic context of the South American late Oligocene: Journal of Paleontology, v. 84, p. 1177-1187.

Cerdeño, E., Montalvo, C., and Sostillo, R., 2017, Deciduous dentition and eruption pattern in late Miocene Pachyrukhinae (Hegetotheriidae, Notoungulata) from La Pampa Province, Argentina: Historical Biology, v. 29, p. 359-375.

Cifelli, R.L., 1985, Biostratigraphy of the Casamayoran, early Eocene, of Patagonia: American Museum Novitates, v. 2820, p. 1-26.

Cifelli, R.L., 1993, Phylogeny of native South American ungulates, in Szalay, F.S., Novacek, M.J., and McKenna, M.C., eds. Mammal Phylogeny, Placentals: New York, Springer-Verlag, p. 195-216.

Cladera, G., Ruigómez, E., Ortiz Jaureguizar, E., Bond, M., and López, G., 2004, Tafonomía de la Gran Hondonada (Formación Sarmiento, EdadMamífero Mustersense, Eoceno Medio) Chubut: Argentina, Ameghiniana, v. 41 , p. $315-330$.

Croft, D.A., and Anderson, L.C., 2008, Locomotion in the extinct notoungulate Protypotherium: Palaeontologia Electronica, 11, 20 p. http://palaeoelectronica.org/2008_1/138/index.html

Croft, D.A., Bond, M., Flynn, J.J., Reguero, M., and Wyss, A.R., 2003, Large archaeohyracids (Typotheria, Notoungulata) from central Chile and 
Patagonia including a revision of Archaeotypotherium: Fieldiana, Geology (New Series), v. 49, p. 1-38.

Damuth, J., 1990, Problems in estimating body masses of archaic ungulates using dental measurements, in Damuth, J., and MacFadden, B.J., eds., Body Size in Mammalian Paleobiology: Estimation and Biological Implications: New York, Cambridge University Press, p. 229-253.

Di Rienzo, J.A., Casanoves, F., Balzarini, M.G., Gonzalez, L., Tablada, M., and Robledo, C.W., InfoStat versión 2016. Grupo InfoStat, FCA, Universidad Nacional de Córdoba, Argentina. URL http://www.infostat.com.ar

Dunn, R., Madden, R., Kohn, M., Schmitz, M., Strömberg, C., Carlini, A., Ré, G., and Crowley, J., 2013, A new high precision U-Pb chronology for middle Eocene-early Miocene South American Land Mammal Ages of the Sarmiento Formation, Gran Barranca, Chubut Province, Argentina: Geological Society of America Bulletin, v. 125, p. 539-555.

Elissamburu, A., 2004, Análisis morfométrico y morfofuncional del esqueleto apendicular de Paedotherium (Mammalia, Notoungulata): Ameghiniana, v. 41, p. $363-380$.

Elissamburu, A., 2012, Estimación de la masa corporal en géneros del Orden Notoungulata: Estudios Geológicos, v. 68, p. 91-111.

Elissamburum, A., and Vizcaíno, S., 2004, Diferenciación morfométrica del húmero y fémur de las especies de Paedotherium (Mammalia, Notoungulata) del Plioceno y Pleistoceno temprano: Ameghiniana, v. 42, p. 159-166

Francis, J.C., 1960, Análisis de algunos factores de confusión en la sistemática genérica de los Mesotheriinae (Notoungulata, Typotheria): Ameghiniana, v. 2 , p. $29-36$.

Gelfo, J.N., Chornogubsky, L., López, G.M., Goin, F.J., and Ciancio, M.R., 2010, Biochronological relationships of the mammal fauna from the Paleogene of Las Violetas, Chubut Province, Argentina: X Congreso Argentino de Paleontología y Bioestratigrafía y VII Congreso Latinoamericano de Paleontología, La Plata, Resúmenes, p. 61-62.

Goloboff, P.A., Farris, J. S., Källersjö, M., Oxelman, B., Ramírez, M.J., and Szumik, C.A., 2003, Improvements to resampling measures of group support: Cladistics, v. 19, p. 324-332.

Goloboff, P.A., Farris, J.S., and Nixon, K., 2008, T.N.T., a free program for phylogenetic analyses: Cladistics, v. 24, p. 774-786.

Hitz, R.B., Flynn, J.J., and Wyss, A.R., 2006, New basal Interatheriidae (Typotheria, Notoungulata, Mammalia) from the Paleogene of central Chile: American Museum Novitates, v. 3520, p. 1-32.

Hitz, R.B., Billet, G., and Derryberry, D., 2008, New interatheres (Mammalia, Notoungulata) from the late Oligocene Salla beds of Bolivia: Journal of Paleontology 82, v. 3, p. 447-469.

ICZN 2000, International Commission on Zoological Nomenclature. International Code of Zoological Nomenclature, 4th Edition: Madrid, Museo Nacional de Ciencias Naturales, CSIC (Spanish version), $156 \mathrm{p}$.

Janis, C.M., 1990, Correlation of cranial and dental variables with body size in ungulates and macropodois, in Damuth, J., and MacFadden, B.J., eds., Body Size in Mammalian Paleobiology: Estimation and Biological Implications: New York, Cambridge University Press, p. 255-299.

Jarman, P.J., 1974, The social organisation of antelope in relation to their ecology: Behaviour, v. 48, p. 215-267.

Krause, J.M., Clyde, W.C., Ibañez-Mejía, M., Schmitz, M.D., Barnum, T., Bellosi, E.S., and Wilf, P., 2017, New age constraints for early Paleogene strata of central Patagonia, Argentina: implications for the timing of South American Land Mammal Ages: Geological Society of America Bulletin, doi: 10.1130/B31561.1.

Madden, R.D., 1997, A new toxodontid notoungulate, in Kay, R.F., Cifelli, R.F., and Flynn, J.J., eds., Vertebrate Paleontology in the Neotropics: The Miocene Fauna of La Venta, Colombia: Washington, D.C., Smithsonian Institution Press, p. 335-354.

Marshall, L.G., Hoffstetter, R., and Pascual, R., 1983, Mammals and Stratigraphy: Geochronology of the Continental Mammal-Bearing Tertiary of South America: Paleovertebrata, Mémoire Extraordinaire, p. 1-93.

Mendoza, M., Janis, C.M., and Palmqvist, P., 2002, Characterizing complex craniodental patterns related to feeding behaviour in ungulates: a multivariate approach: Journal of Zoology, v. 258, p. 223-246.

Mendoza, M., Janis, C.M., and Palmqvist, P., 2006, Estimating the body mass of extinct ungulates: a study on the use of multiple regression: Journal of Zoology (London), v. 270, p. 90-101.

Mones, A., 1982, An equivocal nomenclature: what means hypsodonty?: Paläontologisches Zeitschrift, v. 56, p. 107-111.

Mones, A., 1986, Paleovertebrata Sudamericana. Catálogo sistemático de los vertebrados fósiles de América del Sur. Parte I. Lista preliminar y bibliografía: Courier Forschungsinstitut Senckenberg, v. 82, p. 1-625.

Owen-Smith, R.N., 1988, Megaherbivores. The influence of very large body size on ecology, in Barnes, R.S.K., Birks, H.J.B., Connor, E.F., and Paine, R.T. eds., Cambridge Studies in Ecology: New York, Cambridge University Press, $369 \mathrm{p}$.

Pascual, R., Vucetich, M.G., and Fernández, J., 1978, Los primeros mamíferos (Notoungulata, Henricosborniidae) de la Formación Mealla (Grupo Salta,
Subgrupo Santa Bárbara): sus implicancias filogenéticas, taxonómicas y cronológicas: Ameghiniana, v. 15, p. 366-390.

Raigemborn, M.S., Krause, J.M., Bellosi, E., and Matheos, S.D., 2010 Redefinición estratigráfica del Grupo Río Chico (Paleógeno Inferior), en el norte de la Cuenca del golfo San Jorge: Chubut, Revista de la Asociación Geológica Argentina, v. 67, p. 239-256.

Ré, G.H., Bellosi, E.S., Heizler, M., Vilas, J.F., Madden, R.H., Carlini, A.A., Kay, R.F., and Vucetich, G.M., 2010, in Madden, R.H., Carlini, A.A., Vucetich, M.G., and Kay, R.F., eds., The Paleontology of Gran BarrancaEvolution and Environmental Change through the Middle Cenozoic of Patagonia: Cambridge, Cambridge University Press, p. 46-58.

Reguero, M.A., and Prevosti, F.J., 2010, Rodent-like notoungulates (Typotheria) from Gran Barranca, Chubut Province, Argentina: phylogeny and systematics, in Madden, R.H., Carlini, A.A., Vucetich, M.G., and Kay, R.F., eds., The Paleontology of Gran Barranca-Evolution and Environmental Change through the Middle Cenozoic of Patagonia: Cambridge, Cambridge University Press, p. 148-165.

Reguero, M., Candela, A.M., and Cassini, G.H., 2010, Hypsodonty and body size in rodent-like notoungulates, in Madden, R.H., Carlini, A.A., Vucetich, M.G., and Kay, R.F., eds., The Paleontology of Gran Barranca-Evolution and Environmental Change through the Middle Cenozoic of Patagonia: Cambridge, Cambridge University Press, p 358-367.

Roth, S., 1903, Los ungulados sudamericanos: : Anales del Museo La Plata, Paleontología Argentina, v. 5, p. 1-36.

Roth, S., 1927, La diferenciación del sistema dentario en los ungulados, notoungulados y primates: Revista del Museo La Plata, v. 30, p. 172-255.

Scarano, A., Carlini, A.A., and Illius, A.W., 2011, Interatheriidae (Typotheria; Notoungulata), body size and paleoecology characterization: Mammalian Biology, v. 76, p. 109-114.

Schlosser, M., 1923, 5. Klasse: Mammalia, in von Zittel, K.A., ed., Grundzüge der Paläontologie (Paläozoologie): Munich, R. Oldenbourg, p. 402-689.

Scott, K.M., 1990, Postcranial dimensions of ungulates as predictors of body mass, in Damuth, J., and MacFadden, B.J., eds., Body Size in Mammalian Paleobiology: Estimation and Biological Implications: New York, Cambridge University Press, p. 301-335.

Scott, W.B., 1937, The beginning of the age of mammals: Biological Reviews, v. 12 , p. $1-47$.

Simpson, G.G., 1931, A new classification of mammals: Bulletin of the American Museum of Natural History, v. 59, p. 259-293.

Simpson, G.G., 1935a, Descriptions of the oldest known South American mammals from the Río Chico Formation: American Museum Novitates, v. 793 , p. $1-26$

Simpson, G.G., 1935b, Ocurrence and relationships of the Río Chico fauna of Patagonia: American Museum Novitates, v. 818, p. 1-21.

Simpson, G.G., 1936, Notas sobre los mamíferos más antiguos de la colección Roth: Instituto Museo de la Universidad Nacional de La Plata, Obra del Cincuentenario, v. 2, p. 63-94.

Simpson, G.G., 1945, The principles of classification and a classification of mammals: Bulletin of the American Museum of Natural History, v. 85, p. $1-350$.

Simpson, G.G., 1967a, The Ameghinos' localities for early Cenozoic mammals in South America. Part 2: Bulletin of the American Museum Natural History, v. 136, p. 63-76.

Simpson, G.G., 1967b, The beginning of the age of mammals in South America. Part 2: Bulletin of the American Museum of Natural History, v. 137, p. $1-260$.

Simpson, G.G., 1970, Additions to knowledge of Groeberia (Mammalia Marsupialia) from the mid-Cenozoic of Argentina: Breviora, v. 362, p. $1-17$.

Sinclair, W.J., 1909, Mammalia of the Santa Cruz Beds. Volume 4, Paleontology. Part 1, Typotheria, in Scott, W.B., ed., Reports of the Princeton University Expeditions to Patagonia, 1896-1899: Princeton University, Stuttgart., E. Schweizerbart'sche Verlagshandlung (E. Nägele), p. 1-110.

Stirton, R.A. 1953, A new genus of interatheres from the Miocene of Colombia: University of California Publications in Geological Sciences, v. 29, p. 265-348.

Tejedor, M., Goin, F.J., Gelfo, J.N., López, G., Bond, M., Carlini, A.A., ScillatoYané, G.J., Woodburne, M.O., Chornogubsky, L., Aragón, E., Reguero, M.A., Czaplewski, N.J., Vincon, S., Martin, G.M., and Ciancio, M.R., 2009, New early Eocene Mammalian fauna from western Patagonia, Argentina: American Museum Novitates, v. 3638, p. 1-43.

Tsubamoto, T., 2014, Estimating body mass from the astragalus in mammals: Acta Palaeontologica Polonica, v. 59, p. 259-265.

Vera, B., 2012a, Revisión del género Transpithecus Ameghino, 1901 (Notoungulata, Interatheriidae) del Eoceno medio de Patagonia, Argentina: Ameghiniana, v. 49, p. 60-74.

Vera, B., 2012b, Postcranial morphology of Notopithecus Ameghino, 1897 (Notoungulata, Interatheriidae) from the middle Eocene of Patagonia, Argentina: Journal of Vertebrate Paleontology, v. 32, p. 1135-1148. 
Vera, B., 2013a, La identidad taxonómica de Acoelodus connectus Ameghino, 1901 (Notoungulata) del Eoceno medio de Patagonia: Ameghiniana, v. 50, p. $535-540$.

Vera, B., 2013b, Sistemática, filogenia y paleoecología de los Notopithecinae (Interatheriidae, Notoungulata) del Paleógeno de Argentina [Ph.D. dissertation]: Buenos Aires, Universidad de Buenos Aires, 374 p.

Vera, B., 2016, Phylogenetic revision of the South American notopithecines (Mammalia, Notoungulata): Journal of Systematic Palaeontology, v. 14, p. 461-408.

Vera, B., and Cerdeño, E., 2014, New insights on Antepithecus brachystephanus Ameghino, 1901 and dental eruption sequence in 'notopithecines' (Mammalia, Notoungulata) from the Eocene of Patagonia, Argentina: Geobios, v. 47, p. $165-181$.

Vizcaíno, S.F., Bargo, M.S., Kay, R.F., Fariña, R.A., Di Giacomo, M., Perry, J.M.G., Prevosti, F.J., Toledo, N., Cassini, G.H., and Fernicola, J.C., 2010,
A baseline paleoecological study for the Santa Cruz Formation (late-early Miocene) at the Atlantic coast of Patagonia, Argentina: Palaeogeography, Palaeoclimatology, Palaeoecology, v. 292, p. 507-519.

Woodburne, M.O., Goin, F.J., Bond, M., Carlini, A.A., Gelfo, J.N. López, G.M., Iglesias, A., and Zimicz, A.N., 2014a, Paleogene Land Mammal faunas of South America; a response to global climatic changes and indigenous floral diversity: Journal of Mammal Evolution, v. 21, p. 1-73.

Woodburne, M.O., Goin, F.J., Raigemborn, M.S., Heizler, M., Gelfo, J.N., and Oliveira, E.V., 2014b, Revised timing of the South American early Paleogene land mammal ages: Journal of South American Earth Sciences, v. 54 , p. $109-119$

Accepted 2 May 2017 